Przemystaw Żurawski vel Grajewski

Uniwersytet Łódzki

\title{
Kampania jesienna 2020 r. wojny azersko-ormiańskiej - uwarunkowania historyczne i skutki polityczne
}

$\mathrm{J}$ esienią 2020 r. nastąpił nowy etap, ciągnącej się de facto od blisko 30 lat, wojny ormiańsko-azerskiej o Górski Karabach. Jak dotąd w jej ramach wystąpiły dwa okresy intensywnych walk - pierwszy w latach 1992-1994 - zwycięski dla Ormian, a poprzedzony sięgającym roku 1987 etapem narastania konfliktu i drugi - ostatni będący w istocie ofensywą azerską, przeprowadzoną $\mathrm{w}$ dniach 27 września-10 listopada 2020 r., a skutkującą wyzwoleniem okupowanych od trzech dekad terytoriów Azerbejdżanu i zakończoną porozumieniem pokojowym, podpisanym przez obie strony konfliktu w nocy z 9 na 10 listopada z udziałem Rosji, występującej w roli rozjemcy. Oba etapy intensywnych walk rozdzielone były okresem kruchego rozejmu, naruszanego tak przez Ormian, jak i Azerów i towarzyszących tym starciom bezowocnych negocjacji w ramach Grupy Mińskiej OBWE ${ }^{107}$ (USA, Francja i Rosja z uprzywilejowaną de facto pozycją Rosji jako dominującej w regionie). Ormianie cieszyli się statusem beatis possidentis (szczęśliwych posiadaczy) i świadomi uzyskanej przewagi wojskowej, nie byli skłonni do żadnych ustępstw. Azerbejdżan zaś balansował, najpierw licząc na mediację rosyjską, potem - po 1999 r. dążąc do osłabienia wpływów Rosji, by wreszcie po bierności Zachodu w obliczu rosyjskiego ataku na Gruzję w 2008 r. wrócić znów do ostrożniejszej polityki względem Kremla ${ }^{108}$. Wojna azersko-ormiańska lat 1992-2020, na żadnym jej etapie nie była jednak konfliktem zamrożonym. Między rozejmem z 1994 r. a rokiem 2003 częstotliwość incydentów zbrojnych była wprawdzie niewielka, ale nigdy one zupełnie nie ustały, a po tej dacie możemy już

107 OSCE Minsk Group, https://www.osce.org/mg. Szerzej patrz: R. Czachor, Dynamika inicjatyw międzynarodowych na rzecz regulacji konfliktu w Górskim Karabachu, „Zeszyty Naukowe Wyższej Szkoły Oficerskiej Wojsk Lądowych, nr 3 (173)", 2014, s. 5-19. Por.: Р. Мусабеков, Війна за Нагірний Карабах: на що перетворився старий етнотериторіальний конфлікт, „«Чорноморська безпека» Аналітичний часопис", No 1(39)2021, s.8-9.

${ }^{108}$ Z. Shiriyev, Azerbaijan's Relations with Russia Closer by Default? Research Paper, Russia and Eurasia Programme, March 2019, s.12. 
mówić o stopniowej choć oczywiście nie liniowej eskalacji, z okresami intensyfikacji starć, przeplatanymi okresami względnego spokoju. Fakt ten skłonił mnie do uznania całego owego 29-cio letniego okresu (1992-2021) za jedną długą wojnę, a starć z jesieni 2020 r. za jej najświeższą kampanię. Termin „kampania jesienna 2020 r.” został więc w niniejszym tekście użyty celowo dla podkreślenia rzeczywistego charakteru ostatnich walk. Ma on istotne znaczenie polityczne, gdyż uniemożliwia określenie operacji armii azerbejdżańskiej, prowadzonej na międzynarodowo uznanym terytorium Azerbejdżanu, mianem agresji.

Niżej prezentowany tekst jest analizą wydarzeń wiodących do kampanii jesiennej roku 2020, jej przyczyn, sytuacji w jakiej znalazły się zarówno Armenia, jak i Azerbejdżan w wyniku podjęcia w latach 1987-1994 sporu o Górski Karabach i jej ewolucji, aż po ponowny wybuch intensywnych walk jesienią 2020 r. Podjęta w nim została także próba oceny osiągniętego rezultatu. Przedmiotem moich rozważań nie był zaś sam przebieg kampanii - opis sytuacji wojennej na froncie walk, użytej techniki wojskowej (nawet słynnych tureckich dronów i ich udziału w zwycięstwie Azerbejdżanu ${ }^{109}$ ), nowych rozwiązań technologicznych i taktycznych zaprezentowanych w trakcie tego starcia, kierunków natarć, rozwoju sytuacji na froncie etc. Ten wymiar konfliktu w zakresie publicystycznym i w wymiarze bieżącej analizy fachowych think tanków opisany już został w serii artykułów $^{110}$, a w wymiarze naukowym doczeka się zapewne wkrótce licznych studiów badaczy wojskowych. Niniejsza analiza nie jest więc studium operacji militarnej jako takiej. Interesować nas zaś będzie tło, przyczyny i skutki polityczne omawianej kampanii.

Emocjonalne spojrzenie na obecną odsłonę konfliktu azersko-ormiańskiego tworzy fałszywy obraz „,chrześcijańskiego narodu zagrożonego eksterminacją ze strony wojującego islamu, któremu to narodowi należy się nasza solidarność”. Rzeczywistość jest zaś bardziej skomplikowana. By zatem zrozumieć naturę tego konfliktu, ujrzeć go w całej jego złożoności

\footnotetext{
${ }^{109}$ Szerzej o użyciu tureckich dronów w wojnie o Karabach patrz: J. Palowski, Górski Karabach: Drony uderzeniowe kontra przeciwlotnicze Osy, „Defence24”, 28 września 2020, https://www.defence24.pl/gorskikarabach-drony-uderzeniowe-kontra-przeciwlotnicze-osy. Por.: J. Sabak, Czego uczy nas „wojna dronów” w Górskim Karabachu?, „Defence24”, 16 grudnia 2020, https://www.defence24.pl/potrzebna-zmiana-tytulu-na-ytczego-uczy-nas-wojna-dronow-w-gorskim-karabachu-skaner-defence24 oraz Idem, Górski Karabach: Bezzalogowce wygrywaja wojnę? [Analiza], „Defence24”, 1 października 2020, https://www.defence24.pl/gorski-karabach-bezzalogowce-wygrywaja-wojne-analiza.

110 Jako przykłady publicystyki patrz: В. Заблоцький, Визволення Нагірного Карабаху. Військово-технічні та оперативно-тактичні Аспекти, „«Чорноморська безпека» Аналітичний часопис”, № 1(39)2021, s.2736; M. Świerczyński, Wtaśnie zobaczyliśmy, jak moga wygladać następne wojny, „Polityka”, 6 grudnia 2020, https://www.polityka.pl/tygodnikpolityka/swiat/1981804,1,wlasnie-zobaczylismy-jak-moga-wygladac-nastepnewojny.read. Analizy think tanków: A. M. Dyner, A. Legieć, Wojskowy wymiar konfliktu o Górski Karabach, „Biuletyn PISM”, NR 241 (2173), 26 listopada 2020, s.1-3.
} 
i ze stosowną perspektywą historyczną, sięgnąć musimy do epoki rozpadania się Związku Sowieckiego, przeanalizować okoliczności zainicjowania sporu, zwycięski dla Ormian etap wojny w latach 1992-1994, przyczyny nieskuteczności „procesu pokojowego” i wreszcie drogę ku nowej eskalacji walk i ich wynik. Struktura niniejszego artykułu odpowiada więc wskazanym wyżej zagadnieniom.

\section{Wybuch wojny}

Konflikt o Górski Karabach 27 września 2020 r. wkroczył w nowy etap, ale się tego dnia nie rozpoczął. Pomijając historię sprzed wcielenia tego obszaru do ZSRS i jego przynależność do spoistego jeszcze imperium sowieckiego ${ }^{111}$, współczesne nam starcie rozpoczęło się w październiku 1987 r., kiedy to utworzony przez Ormian Komitet „Karabach” postawił sobie za cel przyłączenie istniejącego wówczas w ramach Azerbejdżańskiej SRS Górsko-Karabaskiego Obwodu Autonomicznego (GKOA) do sowieckiej Armenii i przeprowadzenia $\mathrm{w}$ nim czystki etnicznej $\mathrm{w}$ postaci wysiedlenia stamtąd wszystkich Azerów. Między listopadem 1987 r. a grudniem 1988 r. w zamieszkach ormiańsko-azerskich zginęło 220 osób a ponad 1150 zostało rannych ${ }^{112}$.

7 grudnia 1988 r. Armenię nawiedziło trzęsienie ziemi, w wyniku którego zginęło 25 tys. osób. „Wszechmocna” władza sowiecka okazała się wobec tej katastrofy bezradna. Tragedia ta była dla Armenii silniejszym wstrząsem niż Czarnobyl dla Ukrainy. Zmusiła Ormian do samoorganizacji poza państwem sowieckim. Ta zaś, raz dokonana, wchłonęła także szersze cele narodowe niż doraźna pomoc po katastrofie. Przyłączenie Karabachu było jednym $\mathrm{z}$ nich ${ }^{113}$. Utworzony na przełomie lat 1987-1988 tzn. jeszcze przed trzęsieniem ziemi, wspomniany ormiański Komitet „Karabach” ogłosił program utworzenia Wielkiej Armenii jako państwa narodowego Ormian, (tzn. bez mniejszości narodowych), w granicach obejmujących oprócz terytorium Armeńskiej SRS, także Górski Karabach, Nachiczewan, Armawir, Gandżę, Geranboj, Achalkalaki oraz część Turcji ${ }^{114}$. To z jego inspiracji w GKOA doszło do gwałtownych wystąpień miejscowej większości ormiańskiej przeciw mniejszości azerskiej, która zdając sobie sprawę z własnej słabości liczebnej, nie podjęła konfrontacji

\footnotetext{
111 Szerzej o wcześniejszej historii Górskiego Karabachu w wersji azerskiej patrz: T. Musajew, Kosowo a roszczenia Armenii wobec regionu Górskiego Karabachu Azerbejdżanu. Porównawcza analiza prawna, Warszawa 2013, s. 20-26. Por.: Z. Rokita, Historia konfliktu górskokarabaskiego i jego miejsce w polityce zagranicznej Federacji Rosyjskiej, „Pisma Humanistyczne”, (7), 2010, s.135-137.

112 P. Kwiatkiewicz, Azerbejdżan: uksztaltowanie niepodległego państwa, Toruń 2009, s.64-65.

${ }^{113}$ P. Verluise, Armenia in Crisis: The 1988 Earthquake, Detroit 1995, s.99-140.

${ }^{114}$ P. Kwiatkiewicz, op.cit., s.65-66 i 94-97. Por.: P. Verluise, op.cit., s.133-140.
} 
zbrojnej, ale uciekała się jedynie do pokojowych - nieskutecznych protestów ${ }^{115}$. Zaczęły się też wysiedlenia. Na początku nie cały przepływ ludności miał charakter gwałtowny - oparty na przemocy. Zdarzały się wypadki wymieniania się wiosek azerskich i ormiańskich domami i przeprowadzki z pomocą władz Azerów do Azerbejdżanu a Ormian do Armenii. Spirala nienawiści bez przerwy jednak narastała. Najpierw z małych wiosek a w końcu i ze Stepanakertu wyganiano Azerów siłą $\mathrm{z}$ pozbawieniem ich całości majątku ${ }^{116}$. Azerscy uchodźcy z GKOA przesiedleni zostali do Sumgaitu we wschodnim Azerbejdżanie, gdzie w lutym 1988 r. doszło z kolei do pogromu miejscowych Ormian ${ }^{117}$. Fala wzajemnych pogromów doprowadziła w następnych miesiącach do przemieszczenia się ok. 250 tys. ludzi Azerów uciekających z Karabachu i Ormian z Azerbejdżanu ${ }^{118} .13$ stycznia 1990 r. doszło do pogromu Ormian w Baku (kilkadziesiąt ofiar śmiertelnych), a w dniach 19-20 stycznia 1990 r. po serii prowokacji sowieckich służb, do interwencji wojskowej i pacyfikacji miasta (od 132 do 170 zabitych Azerów - cywilów) ${ }^{119}$. Na tym etapie sporu Moskwa poparła Ormian. Półtora roku później Kreml, dążąc do utrzymania kontroli nad obu zwaśnionymi republikami w kwietniu-czerwcu 1991 r. przeprowadził z kolei wspólnie z azerbejdżańskim OMONem operację „Pierścień”, wysiedlając 19 wiosek ormiańskich w GOKA pod hasłem konfiskaty nielegalnej broni. Był to moment szczytowy poparcia Moskwy dla Azerbejdżanu ${ }^{120}$.

Stosunek sowieckiego centrum do konfliktu azersko-ormiańskiego był zmienny w czasie, ale mimo wyżej opisanej pacyfikacji Baku, do końca do końca istnienia ZSRS - tzn. do schyłku roku 1991, przeważało poparcie dla Azerbejdżanu. Wynikało to z szeregu nakładających się na siebie czynników. Azerbejdżan w tym czasie w odróżnieniu od Armenii, nie posiadał ambicji niepodległościowych, lecz opowiadał się za zachowaniem status quo

\footnotetext{
${ }^{115}$ P. Kwiatkiewicz, op.cit., s.74-75, 80. Lista aktów przemocy ormiańskiej wymierzonych w ludność azerską według strony azerskiej patrz: F. Wagabow (red.), Górny Karabach. Wydarzenia, fakty, liczby, Baku-Weten, 2005, s.23-31. Pierwszymi zabitymi w tym konflikcie było dwóch Azerów w Ağdamie - dzielnicy Askeranu miasta w GOKA. P. Мусабеков, оp.cit., s.5.

${ }^{116}$ P. Мусабеков, ор.cit., s.7.

${ }^{117}$ Szerzej patrz: Ibidem, s.77-81. Por.: O. Geukijan, Ethnicity, Nationalism and Conflict in the South Caucasus. Nagorno-Karabakh and the Legacy of Soviet Nationality Policy, Ashgate 2012, s.146-148 oraz Z. Rokita, op.cit., s.138.

${ }^{118}$ T. Świętochowski, Azerbejdżan, Warszawa 2006, s.165.

${ }^{119}$ P. Kwiatkiewicz, Przemiany polityczne w Azerbejdżanie. Od republiki radzieckiej do wspótczesnego państwa. Toruń 2013, s.171-172. Por.: T. Świętochowski, Azerbejdżan i Rosja. Kolonializm, islam i narodowość w podzielonym kraju, Warszawa 1998, s.240-241 oraz W. Górecki, Kaukaski węzet gordyjski. Konflikt o Górski Karabach, „Raport OSW”, 5/2020, s.36.

${ }^{120}$ Wywołało to gwałtowne deklaracje polityków ormiańskich. 5 maja 1991 r. przewodniczący armeńskiej Rady Najwyższej Lewon Ter-Petrosjan oświadczył, że ZSRS wypowiedział wojnę Armenii, a 17 maja na zamkniętej sesji Rady przyjęto uchwałę, w której metody stosowane przez oddziały sowieckie i azerbejdżańskie w operacji „Pierścień” określono jako noszące znamiona ludobójstwa. W. Górecki, op.cit., s.35.
} 
w ramach ZSRS. Ormianie dążyli zaś już do utworzenia własnego państwa. W 1990 r. zmienili nazwę swego kraju z Armeńskiej Socjalistycznej Republiki Sowieckiej na Republikę Armenii, nawiązując do tradycji Demokratycznej Republiki Armenii z lat 1918-1920. W marcu 1991 r. zbojkotowali masowo Gorbaczowowskie referendum na temat zachowania istnienia Związku Sowieckiego. Azerowie (z wyjątkiem rządzonego przez Hejdara Alijewa obwodu nachiczewańskiego), głosowali zaś w nim zgodnie z oczekiwaniami Moskwy ${ }^{121}$. Ten nurt polityki moskiewskiej załamał się jednak wraz z upadkiem sowietów, niezdolnych już do odziaływania na bieg wydarzeń.

Podjęta przez prezydentów Rosji i Kazachstanu jeszcze w ramach rozpadającego się ZSRR, próba mediacji między Ormianami a Azerami (tzw. Proces Żeleznowodzki) załamała się wobec zestrzelenia 20 listopada 1991 r. przez terrorystów ormiańskich śmigłowca z grupą 18 wysoko postawionych polityków azerbejdżańskich, kazachskich i rosyjskich oraz czteroosobową załogą na pokładzie ${ }^{122}$. Rozpad ZSRR w grudniu 1991 r. postawił niepodległe już Azerbejdżan i Armenię przeciw sobie.

\section{Secesja Górskiego Karabachu, sojusz Armenii z Rosją, czystki etniczne i zwycięstwo Ormian}

Proces secesji Górskiego Karabachu z Azerbejdżańskiej SRS postępował między rokiem 1988 a 1991. 20 lutego 1988 r. władze GOKA złożyły do centralnych władz sowieckich wniosek o wyłączenie tej autonomicznej prowincji z Azerskiej SRS i przekazanie jej do Armeńskiej SRS. Skutkiem było ogłoszenie na tym obszarze stanu nadzwyczajnego i przejęcie władzy nad nim bezpośrednio przez Moskwę. Mimo to 1 grudnia 1989 r. Rada Najwyższa Armenii ogłosiła włączenie Górskiego Karabachu w skład Armeńskiej SRS, a 2 września 1991 r. władze GOKA proklamowały powstanie Republiki Górskiego Karabachu. W odpowiedzi władze Azerskiej SRS zniosły autonomię GOKA, na co Ormianie z Górskiego Karabachu zareagowali przeprowadzeniem 10 grudnia 1991 r. referendum niepodległościowego. Akt ten po dokonanych już czystkach etnicznych dał łatwy do przewidzenia rezultat. Mimo, że referendum zostało zbojkotowane przez Azerów, wzięło w nim udział 82,2\% uprawnionych, a 99,9\% z nich opowiedziało się za niepodległością, zaś tylko $0,02 \%$ przeciw. W konsekwencji, powołując się na te wyniki, 6 stycznia 1992 r. nowo wybrana władza ustawodawcza prowincji ogłosiła odłączenie się od Azerbejdżanu

\footnotetext{
${ }^{121}$ Z. Rokita, op.cit., s.144.

${ }^{122}$ P. Мусабеков, оp.cit., s.6-7. O zestrzeleniu śmigłowca i śmierci 22 osób patrz też: F. Wagabow, op.cit., s.2627.
} 
i proklamowała niepodległość Republiki Górskiego Karabachu oraz jego podmiotowość prawno-międzynarodową, a także wprowadzenie obywatelstwa Republiki Górskiego Karabachu ${ }^{123}$.

Secesja GOKA i proklamacja niepodległości doprowadziły do wybuchu wojny ormiańsko-azerskiej. Działania zbrojne weszły w fazę intensywną w lutym 1992 r. Moskwa początkowo balansowała między walczącymi stronami ze wskazaniem na Azerbejdżan. Ta względna przychylność wobec Azerbejdżanu wynikała z faktu, że w Erywaniu rządzili wówczas demokraci, którzy starali się prowadzić niezależną politykę zagraniczną, natomiast w Baku u władzy pozostawali zorientowani na Rosję komuniści, na czele $\mathrm{z}$ Ajazem Mutalibowem $^{124}$, ostatnim pierwszym sekretarzem Komunistycznej Partii Azerbejdżanu. Przemiany w samej Rosji, gdzie Jelcyn prowadził politykę zwalczania komunistów, także wpływały jednak od końca 1991 r. na stosunek Moskwy do skonfliktowanych stron na Kaukazie.

Klęski ponoszone przez siły azerskie na froncie walk z Ormianami skutkowały upadkiem Mutalibowa 6 marca 1992 r. i przejęciem władzy w Baku przez Ludowy Front Azerbejdżanu. Mimo prób powrotu, Mutalibow ostatecznie uciekł do Moskwy, a wybory w Azerbejdżanie (7 VI 1992). Wygrał przywódca LFA, zwolennik zbliżenia z Zachodem i orientacji na Turcję - Abulfaz Elczibej ${ }^{125}$. Zwrot Azerbejdżanu ku Turcji i pomoc turecka dla Baku, odrodzenie się idei panturańskich i perspektywa budowy przez konsorcjum zachodnich firm naftowych ropociągu umożliwiającego tranzyt ropy naftowej poza kontrolą Rosji z basenu Morza Kaspijskiego na Zachód, poważnie zaniepokoiły Moskwę. Kreml równolegle do zmian na scenie politycznej Azerbejdżanu zmieniał więc wektory swej polityki i ostatecznie zdecydowanie poparł wojskowo Armenię ${ }^{126}$, której Rosja przekazała broń i sprzęt za ponad 1 mld USD (Dla ujrzenia tej pomocy we właściwej skali dodajmy, że przy kolejnej intensyfikacji walk w 2016 r. budżet wojskowy Armenii, mimo, że pochłaniał aż 3,8

\footnotetext{
${ }^{123}$ S. Kolarz, Status prawny Górskiego Karabachu - porównanie ze statusem prawnym Kosowa, „Folia Iuridica Universitatis Wratislaviensis", vol. 5(1), 2016, s.122.

${ }^{124}$ W. Górecki, op.cit., s.36-37. Odmienną interpretację podaje (P. Мусабеков, ор.cit.,7), twierdząc, że sympatie Jelcyna były po stronie rządzonej przez demokratów Armenii, a nie starej nomenklatury komunistycznej, której przedstawicielem w Azerbejdżanie był Mutalibow, a z którą (choć sam się z niej wywodził) w samej Rosji Jelcyn był w konflikcie. Oba poglądy nie muszą być wzajemnie sprzeczne. Stanowisko Moskwy było niewątpliwie zmienne w czasie, podobnie jak i osoba decydenta na Kremlu - inna przed, a inna po rozpadzie ZSRR. Zmiana $\mathrm{w}$ Moskwie $\mathrm{z}$ uwagi na inercję polityczną pogrążonego w kryzysie rozpadu aparatu państwowego ZSRR/Rosji nie musiała też skutkować natychmiastową zmiana polityki Moskwy wobec konfliktu azersko-ormiańskiego.

${ }^{125}$ P. Kwiatkiewicz, Przemiany polityczne..., s. 251-253; T. Świętochowski, Azerbejdżan..., s. 145-147.

${ }^{126}$ W. Górecki, op.cit., s.36-37. Por.: Z. Shiriyev, op.cit., s.6.
} 
\% PKB, wyniósł tylko 412 mln USD) ${ }^{127}$. Potężne ilości nowoczesnego jak na warunki tej kaukaskiej wojny uzbrojenia dostarczone przez Rosję Ormianom ${ }^{128}$, w praktyce rozstrzygnęły o wyniku walk.

W lutym 1992 r., a zatem jeszcze przed ostatecznym zwrotem polityki rosyjskiej, armia Armenii i siły Górskiego Karabachu zadały klęskę wojskom Azerbejdżanu i zajęły strategicznie ważne miasto Şuşa oraz korytarz lacziński, uzyskując tym samym terytorialne połączenie Górskiego Karabachu z Armenią właściwą ${ }^{129}$. Postępom ofensywy ormiańskiej towarzyszyły czystki etniczne w tym masakry cywilów azerskich, z których najsłynniejsza i największa miała miejsce w Xocalı (25/26 II 1992) - 613 zabitych w tym 106 kobiet i 83 dzieci. Współodpowiedzialnym za tę zbrodnię był także rosyjski 366 pułk piechoty zmotoryzowanej, biorący udział $w$ ataku na Xocalı i zaopatrujący Ormian w broń $\mathrm{i}$ amunicję $e^{130}$. Okrucieństw dopuszczały się obie strony, ale zgodnie $\mathrm{z}$ naturą wojen etnicznych, strona zwycięska - tzn. Ormianie - dokonywała ich więcej ${ }^{131}$.

15 maja 1992 r. Armenia przystąpiła do sojuszu wojskowego z Rosją w ramach traktatu taszkienckiego jako jedno $\mathrm{z}$ jego państw założycielskich ${ }^{132}$. Wsparci i dozbrojeni przez Moskwę Ormianie pokonali Azerów w kolejnej ofensywie podjętej między czerwcem a październikiem 1993 r., w której opanowali tereny między GOKA a Armenią oraz GOKA a Iranem, na których ludność azerska stanowiła ok $90 \%$ populacji ${ }^{133}$, Doprowadziło to do upadku Elczibeja, objęcia władzy w Baku przez Hejdara Alijewa (ojca obecnego prezydenta) i przystąpienia Azerbejdżanu do WNP, a zatem jego powrotu do rosyjskiej strefy wpływów ${ }^{134}$. 24 września 1993 r. Azerbejdżan, chcąc uniknąć dalszych strat na rzecz

127 Armenia $i$ Azerbejdżan - czyja armia jest silniejsza?, „Kresy24.pl”, 7 kwietnia 2016, https://kresy24.pl/armenia-i-azerbejdzan-czyja-armia-jest-silniejsza/.

${ }^{128}$ Szczegóły o ilości i rodzajach broni i sprzętu dostarczonego przez Rosję Ormianom patrz: Современное состояние ПВО стран - бывщих советских союзных республик. Часть 6-я, „Военное обозрение”, 14 октября 2016, https://topwar.ru/101936-sovremennoe-sostoyanie-pvo-stran-byvshih-sovetskih-soyuznyhrespublik-chast-6-ya.html.

${ }^{129}$ P. Kwiatkiewicz, Azerbejdżan..., s.166-168. Por.: P. Мусабеков, ор.cit., s.7.

${ }^{130}$ Bloodshed in the Caucasus. Escalation of the Armed Conflict in Nagorno-Karabakh, September 1, 1992, Human Rights Watch / Helsinki (former Helsinki Watch), s. 19-24. Patrz też: F. Wagabow, op.cit., s.31. Por.: H. Womack, Refugees and fresh graves confirm massacre by Armenians - Azeris hunted down and shot in the forest, "The Independent", 5 March 1992, opublikowany na portal: "Justice for Khojaly", https://justiceforkhojaly.org/content/refugees-and-fresh-graves-confirm-massacre-armenians-\%E2\%80\%93azeris-hunted-down-and-shot-forest.

${ }^{131}$ Szerzej patrz: Bloodshed in the Caucasus. Escalation of the Armed Conflict in Nagorno-Karabakh... s.19-44.

132 M. Sadłowski, Organizacja Układu o Bezpieczeństwie Zbiorowym. Prawno-instytucjonalne aspekty funkcjonowania, Toruń 2017, s. 22.

${ }^{133}$ W. Górecki, op.cit., s.58

${ }^{134}$ Ibidem, s. 37. 
sprzymierzonej z Moskwą Armenii, także przystąpił do traktatu taszkienckiego ${ }^{135}$. W maju 1994 r., wobec załamania się azerskiej ofensywy i zagrożenia zdobyciem przez Ormian drugiego co do wielkości miasta Azerbejdżanu - Giandży, Baku poprosiło o rozejm, który skończył ten etap wojny ${ }^{136}$.

W trakcie wyżej opisanego pierwszego etapu wojny ormiańsko-azerskiej o Górski Karabach sympatia świata była wyraźnie po stronie Ormian. Byli oni wspierani nie tylko przez Rosję, ale i przez silną diasporę ormiańską, cieszącą się dużymi wpływami politycznymi i zdolnością do kształtowania opinii publicznej w tym $\mathrm{w}$ tak ważnych państwach jak Stany Zjednoczone i Francja ${ }^{137}$.

\section{Dziel i rządź - schemat rosyjskiej rekonsolidacji przestrzeni postsowieckiej}

Zwycięstwo Ormian oddało Azerbejdżan z powrotem pod wpływy Rosji. Schemat: 1) próba oderwania się od Moskwy - 2) wspierana przez Kreml secesja regionu - 3) powrót do rosyjskiej strefy wpływów - powtórzony był w tym czasie przez Rosję wobec Mołdawii (Naddniestrze i Gagauzja) ${ }^{138}$ oraz Gruzji (Abchazja i Osetia Południowa) ${ }^{139}$. Próbowała ona rozegrać ten scenariusz także w relacjach polsko-litewskich, na szczęście bez powodzenia ${ }^{140}$. Konflikt ormiańsko-azerski był jego pierwszym poligonem. Moskwa, stosując zasadę „dziel

\footnotetext{
135 P. Kwiatkiewicz, Przemiany polityczne..., s.348.

${ }^{136}$ R. Czachor, op.cit., s.7.

137 J. Potocki, Kaukaska kwadratura, Warszawa 2012, s. 10. J. Potocki (ibidem) twierdzi też, że USA udzieliły Armenii najwyższej poza Izraelem w przeliczeniu na jednego mieszkańca pomocy wojskowej, nie podaje jednak źródła tej informacji.

138 Szerzej patrz: J. Darski, Rumunia. Historia, współczesność, konflikty narodowe, Warszawa 1993, s.123-129. Por.: M. Kuczyński, Krwawiaca Europa. Konflikty zbrojne i punkty zapalne w latach 1990-2000. Tło historyczne i stan obecny, Warszawa 2001, s.71-79 oraz J. Wróbel, Naddniestrze, [w:] K. Strachota (red.), Konflikty na obszarze postradzieckim. Stan obecny. Perspektywy uregulowania. Konsekwencje, „Prace OSW”, nr 9, Warszawa, czerwiec 2003, s.15-19, a także: J. Solak, Mołdawia. Republika na trzy pęknięta. Historycznospołeczny, militarny i geopolityczny wymiar ,,zamrożonego konfliktu o Naddniestrze, Toruń 2009, 75-91, 101116.

139 Szerzej patrz: W. Materski, Gruzja, Warszawa 2000, s.256-270. Por.: W. Bartuzi, Gruziński kocioł między Abchazją, Osetia południowa a Adżariq 1991-2006, [w:] P. Ostaszewski (red.), Konflikty kolonialne $i$ postkolonialne w Afryce i Azji 1869-2006, Warszawa 2006, s.801-813. Patrz też.: A. Eberhardt, Armed Conflicts in Georgia: the Russian Factor, [w:] A. Eberhardt i A. Iwashita (red.), Security Challenges in the Post-Soviet Space. European and Asian Perspectives, Warszawa-Sapporo 2007, s.136-146.

${ }^{140} \mathrm{O}$ wstępnym etapie inicjowanego przez Moskwę procesu skłócania Polaków z Litwinami poprzez straszenie Litwinów „polskim imperializmem”, a Polaków „litewskim nacjonalizmem” w dobie pieriestrojki patrz: M. Maszkiewicz, Repatriacja czy repatriotyzacja? Wybrane problemy polskich strategii politycznych wobec rodaków za wschodnia granica (1986-1990), s. 133-142, 217-219, 268-270. O konflikcie wokół autonomii Wileńszczyzny w okresie rozpadania się ZSRR szerzej patrz: B. Jundo-Kaliszewska, Zaktadnicy historii. Mniejszość polska $w$ postradzieckiej Litwie, Łódź 2019, s. 85-272. Por.: P. Żurawski vel Grajewski, Polska polityka wschodnia 1989-2015. Wymiar narodowy i unijny, Kraków 2016, s.67-72 oraz P. Sobik, Akcja Wyborcza Polaków na Litwie w systemie politycznym Republiki Litewskiej, Wojnowice 2017, s.143-176.
} 
i rządź”, stała się arbitrem w tlącym się sporze jako „sojusznik Armenii” i „strategiczny partner Azerbejdżanu” ${ }^{141}$. Górski Karabach został „oczyszczony” z Azerów, Azerbejdżan zaś z Ormian. Z opanowanych przez Ormian terenów uciekło kilkaset tysięcy Azerów (Przed ofensywą azerską z 2020 r. status uchodźcy w Azerbejdżanie miało około 600 tysięcy osób) ${ }^{142}$. Siły ormiańskie zajęły jednak nie tylko prawie całą sporną prowincję ${ }^{143}$, ale i obszar między nią a Armenią właściwą, jak też strefę buforową wokół Górskiego Karabachu W sumie ok. 14 \% terytorium uznawanego przez społeczność międzynarodową za integralną część Azerbejdżanu ${ }^{144}$. W rękach ormiańskich znalazły się w całości rejony laczyński (71 tys. mieszkańców), kelbadżarski (74 tys.), dżebraiłski (66 tys.), zengelański (39,5 tys.) i kubatliński (37,9 tys.), a dodatkowo jeszcze fragmenty rejonów agdamskiego (całość regionu to 165 tys. ludzi) i fizulińskiego (całość - 146 tys.) ${ }^{145}$. Poza terytorium dawnego GKOA Ormianie od 1994 r. okupowali zatem w całości pięć, a w części dwa rejony Azerbejdżanu właściwego. Dało to Górskiemu Karabachowi bezpośrednie szerokie lądowe połączenie z Armenią właściwą i kontrolę nad 200 kilometrowym pasem pogranicza azerskoirańskiego. Osiągnięta linia uznawana była przez Ormian za „optymalną z wojskowego punktu widzenia" $" 146$.

Z obszarów okupowanych przez Ormian wyrzucono całą ludność nie tylko azerską, ale i w ogóle muzułmańską w tym także Kurdów. Z Armenii do Azerbejdżanu uciekło ok. 186 tys. Azerów spośród ok. 160 tys. zanotowanych tam w ostatnim przed wojną spisie z 1979 r. (różnica in plus między 1979 a 1994 wynika z silnego przyrostu demograficznego) oraz ok. 18 tys. Kurdów-muzułmanów i ok. 4 tys. Rosjan (razem ok. 208 tys. osób). Łącznie z GKOA i ,terenów okupowanych” latach 1991-1994 uciekło ok. 500 tys. Azerów i Kurdów. Ponadto władze azerbejdżańskie wysiedliły w ramach ewakuacji ludności ze strefy przyfrontowej ok.

\footnotetext{
${ }^{141}$ Szerzej o naturze polityki rosyjskiej wobec tego regionu patrz: M. Falkowski, Polityka Rosji na Kaukazie Poludniowym i w Azji Centralnej / Russia's policy in the Southern Caucasus and Central Asia, „Prace OSW”, nr 23, Warszawa czerwiec 2006 / Warsaw June 2006, s.13-16 / 55-58. O polityce Azerbejdżanu - balansowania między Rosją a Zachodem patrz: Z. Shiriyev, op.cit., s.6-11.

${ }^{142}$ A. Jarosiewicz, M. Falkowski, Wojna czterodniowa w Górskim Karabachu, „Analizy OSW”, 6.04.2016, https://www.osw.waw.pl/pl/publikacje/analizy/2016-04-06/wojna-czterodniowa-w-gorskim-karabachu.

143 Poza kontrolą Ormian karabaskich $\mathrm{z}$ dawnego terytorium GOKA pozostała jedynie część rejonu szaumianowskiego oraz mardakerckiego, które przez samozwańczą Republikę Górskiego Karabachu były uznawane za tereny okupowane przez Azerbejdżan. R. Czachor, op.cit., s.7.

144 A. Jarosiewicz, K. Strachota, Górski Karabach - rozmrażanie konfliktu, „Komentarze OSW”, nr 65, 26.10.2011, s.1. Azerowie mówią o 20\% terytorium. M. Mehdiyev, Baku Denies Speculations About Joining Russia-led Military Bloc, "Caspian News", September 20, 2019, https://caspiannews.com/news-detail/bakudenies-speculations-about-joining-russia-led-military-bloc-2019-9-20-0/.

${ }^{145}$ A. Jarosiewicz, M. Falkowski, op.cit. Por.: F. Wagabow, op.cit., s.6.

${ }^{146}$ R. Czachor, op.cit., s.7.
} 
30 tys. ludzi $\mathrm{z}$ terenów graniczących $\mathrm{z}$ Armenią ${ }^{147}$. Armenia wraz $\mathrm{z}$ Karabachem i okupowanymi terenami oderwanymi od Azerbejdżanu stała się „najczystszym etnicznie” państwem na Kaukazie. W 1988 r. w GKOA obejmującym 4388 km² żyło 189085 osób, w tym 145450 (76,9\%) Ormian, 40688 (21,5\%) Azerów, 1922 (1\%) Rosjan i 1025 (0,6\%) przedstawicieli innych narodowości ${ }^{148}$. W wyniku ormiańskiego zwycięstwa i przeprowadzonych czystek etnicznych w trakcie wojny lat 1992-94 sam Górski Karabach pod panowaniem ormiańskim obejmujący obszar $4500 \mathrm{~km}^{2} \mathrm{z}$ ludnością liczącą 138 tys. osób stał się monoetniczny - 99,4\% jego ludności to Ormianie, a według spisu powszechnego z 2005 r. zamieszkiwało go jedynie sześciu Azerów ${ }^{149}$. Liczba wysiedleńców ze wszystkich obszarów zdobytych przez Ormian w Azerbejdżanie w 1994 r. sięgnęła zaś 750 tys., co stanowiło wówczas ok. $10 \%$ ludności tego kraju ${ }^{150}$. Walki wygasły w 1994 r. - nastąpił rozejm, ale pokoju nigdy nie zawarto. Odtąd dziennie notowano 20-30 przypadków jego naruszenia, a rocznie ginęło ok. 200 osób. Poważniejsze incydenty miały miejsce w marcu 2008 r. (12 zabitych) i w czerwcu 2010 r. (ok. 10 zabitych) ${ }^{151}$, a do intensywniejszych walk doszło jeszcze w trakcie tzw. „wojny czterodniowej (2-5 kwietnia 2016 r. - ok. 110 zabitych) $)^{152}$ i ostatnio w kwietniu i w lipcu $2020 \mathrm{r}^{153}$.

\section{Motywy wznowienia konfliktu w 2020 r. - gra w czworokącie: Azerbejdżan-Turcja-Armenia-Rosja}

Podstawową przyczyną wybuchu walk we wrześniu 2020 r. było fiasko 30-letnich wysiłków dyplomatycznych na rzecz pokojowego rozwiązania konfliktu. Ormianie nie potrafili wykorzystać do uregulowania sporu swej chwilowej przewagi, zdobytej w latach 1992-1994, traktując ją jako rzecz trwałą. Nie zaoferowali Azerbejdżanowi nic w okresie, gdy mogli negocjować z pozycji siły i gdy częściowe choćby ustępstwa, oparte na zasadzie

\footnotetext{
${ }^{147}$ W. Górecki, op.cit., s.28. Zmiany demograficzne w GOKA na podstawie kolejnych pięciu spisów sowieckich z lat 1926-1979 patrz: P. Мусабеков, ор.cit., s.6.

${ }^{148}$ F. Wagabow, op.cit., s.4.

${ }^{149}$ Z. Rokita, op.cit., s. 135 .

${ }^{150}$ W. Górecki, op.cit., s.28.

151 R. Gusejnow, Arytmetyka konfliktu karabaskiego, „Portal Geopolityka.org”, 13 lipca 2010, http://www.geopolityka.org/programy/panstwa-nieuznawane/gorski-karabach/rizwan-gusejnow-arytmetykakonfliktu-karabaskiego.

152 A. Jarosiewicz, M. Falkowski, op.cit. Por.: A. M. Dyner, K. Zasztowt, Eskalacja konfliktu w Górskim Karabachu - przyczyny i prawdopodobny dalszy przebieg, „Biuletyn PISM”, nr 26 (1376), 5 kwietnia 2016, s.12. Patrz też: What Is Russia's Role in the Armenia-Azerbaijan Conflict?, "The Moscow Times", September 28, 2020, https://www.themoscowtimes.com/2020/09/28/what-is-russias-role-in-the-armenia-azerbaijan-conflicta71567.

${ }^{153}$ W. Górecki, op.cit., s.6.
} 
dążenia do granic etnicznych i połączone ze zwrotem istotnej części okupowanych ziem azerbejdżańskich poza GOKA, mogły wieść do pacyfikacji sporu. Nie dostrzegli, że czas działa na ich niekorzyść. Tymczasem Armenia słabła, a Azerbejdżan rósł w siłę. Brak podjętego na czas rozwiązania politycznego musiał więc skutkować rozwiązaniem zbrojnym. Obok tej podstawowej przyczyny wybuchu intensywnych walk, każdy z uczestników gry wokół Górskiego Karabachu miał jednak także własne, bardziej szczegółowe i specyficzne motywy, by zaangażować się w ten czy w inny sposób w ów konflikt.

Azerbejdżan w 1999 r. - w okresie największego osłabienia Rosji pod koniec rządów Jelcyna, wystąpił z Organizacji Układu o Bezpieczeństwie Zbiorowym (OUBZ), w którą w międzyczasie przekształcił się układ taszkiencki, zerwał więc sojusz z Rosją i powtórnie zwrócił się ku Turcji. Armenia pozostaje w OUBZ sojusznikiem Rosji do dziś i gości na swym terytorium 102 rosyjską bazę wojskową w Giumri ${ }^{154}$ oraz bazę lotniczą nr $3624^{155}$. Azerbejdżan pozbył się ostatniej w 2012 r. Prorosyjski zwrot w polityce tureckiej w 2016 r. znów zwiększył wpływy Rosji w Baku. Narastanie sprzeczności rosyjsko-tureckich w Syrii, Libii i na Cyprze obecnie zaś ponownie odwróciło tę tendencję.

Prężny demograficznie i bogaty w ropę naftową Azerbejdżan od 1994 r. spotężniał, Armenia zaś zbiedniała i skurczyła się ludnościowo ${ }^{156}$. Począwszy od 2005 r. skokowo rosnące dochody z ropy naftowej pozwoliły Azerbejdżanowi na intensywne zbrojenia. Jego budżet wojskowy wzrósł w latach 2003 - 2011 ze $135 \mathrm{mln}$ USD do 3,12 mld USD, co stanowiło ok. $20 \%$ wydatków budżetowych tego kraju; ale wynosiło więcej niż cały budżet Armenii ${ }^{157}$. Tendencja ta została wzmocniona przez przyjęcie 22 października $2010 \mathrm{r}$. ambitnego programu zbrojeń, realizowanego począwszy od roku budżetowego $2011^{158}$. Broń kupowano z Rosji, Turcji i Izraela. Przy walnym udziale Turcji intensywnie szkolono

\footnotetext{
154 W Armenii funkcjonuje 102. rosyjska baza wojskowa podległa dowództwu Południowego Okręgu Wojskowego. Stacjonuje tam 3300 rosyjskich żołnierzy, a ich liczba może zostać zwiększona do 5000 . Formalnie celem rosyjskiego kontyngentu wojskowego umieszczonego $w$ tej bazie jest ochrona $w$ ramach OUBZ południowej granicy Rosji we współpracy z siłami zbrojnymi Armenii. A. M. Dyner, Znaczenie zagranicznych baz wojskowych dla Rosji, „Biuletyn PISM”, nr 112 (2044), 25 maja 2020, s.1.

${ }^{155}$ E. Jafarova, Russian military shipments to Armenia - a dangerous escalation?, "Euractiv", 31 sierpnia 2020, https://www.euractiv.com/section/azerbaijan/opinion/russian-military-shipments-to-armenia-a-dangerousescalation/.

${ }^{156}$ J. Potocki, op.cit., s.12-14.

${ }^{157}$ A. Jarosiewicz, K. Strachota, op.cit., s.3.

${ }^{158}$ Azerbejdżan się zbroi, „Analizy OSW”, 27.10.2011, https://www.osw.waw.pl/pl/publikacje/analizy/2010-1027/azerbejdzan-sie-zbroi.
} 
też wojsko, w tym kadrę oficerską ${ }^{159}$, której dojmujący brak zaważył na działaniach wojennych strony azerskiej w latach 1992-1994. W roku 2019 - ostatnim pełnym przed kampanią 2020 r. - bilans sił obu stron wyraźnie wskazywał na przewagę Azerbejdżanu (patrz tabela). W czerwcu 2020 r. Azerbejdżan dodatkowo wzmocnił swój potencjał wojskowy otrzymanymi z Turcji dronami TB2 Bayraktar ${ }^{160}$. Ormianie nie dysponowali tego typu uzbrojeniem.

Bilans potencjału wojskowego Armenii i Azerbejdżanu w 2019 r.

\begin{tabular}{|l|r|r|}
\hline Państwo & \multicolumn{1}{|c|}{ Armenia } & \multicolumn{1}{|c|}{ Azerbejdżan } \\
\hline Wydatki na zbrojenia & 673 mln USD & 1,854 mld USD \\
\hline Żołnierze służby czynnej & 45 tys. & 131 tys. \\
\hline Rezerwiści & 200 tys. & 850 tys. \\
\hline Samoloty myśliwskie & 5 & 35 \\
\hline Samoloty bombowe/szturmowe & 14 & 31 \\
\hline Śmigłowce szturmowe & 17 & 38 \\
\hline Śmigłowce transportowe & 17 & 43 \\
\hline Czołgi & 320 & 2600 \\
\hline Bojowe wozy piechoty & 750 & 285 \\
\hline Holowane zestawy artyleryjskie & 200 & 389 \\
\hline Artyleria samobieżna & 38 & 450 \\
\hline Wieloprowadnicowe wyrzutnie pocisków rakietowych & 70 & 4 \\
\hline Rakietowe systemy wojsk lądowych & 16 & (17 \\
\hline
\end{tabular}

Źródło: A. M. Dyner, A. Legieć, Wojskowy wymiar konfliktu o Górski Karabach, „Biuletyn PISM”, NR 241 (2173), 26 listopada 2020, s. 3

Załamanie się cen ropy naftowej, podkopało jednak stabilność gospodarczą Baku i pogorszyło nastroje społeczne w Azerbejdżanie, które uległy poważnemu zachwianiu już w 2016 r. ${ }^{161}$. Wówczas niezadowolenie społeczne Azerów w znacznej mierze zostało rozładowane wspomnianą wyżej „wojną czterodniową”, która doprowadziła do lokalnych

${ }^{159}$ P. Мусабеков, op.cit., s.10. Por.: Г. Васадзе, Політолог, ведучий програми «Велика гра», Тбілісі, Грузія Війна за Нагірний Карабах. Погляд з Грузї̈, „«Чорноморська безпека» Аналітичний часопис”, № 1(39)2021, s.24-25.

160 B.E. Bekdil, Azerbaijan to buy armed drones from Turkey, "Defense News", June 25, 2020, https://www.defensenews.com/unmanned/2020/06/25/azerbaijan-to-buy-armed-drones-from-turkey/.

161 A. Jarosiewicz, Azerbejdżan - niskie ceny ropy testem dla stabilności, „Analizy OSW”, 12.02.2015, https://www.osw.waw.pl/pl/publikacje/analizy/2015-02-12/azerbejdzan-niskie-ceny-ropy-testem-dla-stabilnosci Por.: Ida, Azerbejdżan - gniew ludu, „Analizy OSW”, 20.01.2016, https://www.osw.waw.pl/pl/publikacje/analizy/2016-01-20/azerbejdzan-gniew-ludu. 
sukcesów armii azerbejdżańskiej i wyzwolenia spod okupacji ormiańskiej kilkunastu kilometrów kwadratowych terytorium. Jej znaczenie materialne było więc niewielkie, ale moralne bardzo istotne. Azerowie pozbyli się kompleksu niższości wojskowej, a mit „niezwyciężonej armii ormiańskiej” został silnie nadwerężony ${ }^{162}$. Starcie z 2016 r. określone zostało mianem „rozpoznania bojem” nowych zdolności armii azerbejdżańskiej w walce z siłami ormiańskimi. Płynące z niego wnioski były dla Baku optymistyczne. Otwierały więc drogę do zaplanowania i przeprowadzenia kampanii roku 2020 $0^{163}$. Jednocześnie postawa Rosji w kwietniu 2016 r. stała się powodem rozczarowania obu stron konfliktu, oczekujących od Moskwy bardziej jednoznacznego stanowiska - oczywiście każda w nadziei, że to ją poprą Rosjanie. Osłabiło to prestiż Kremla i szczególnie w Azerbejdżanie wzmocniło wolę poszukiwania rozstrzygnięcia manu militari ${ }^{164}$. Niezadowolenie społeczne było istotnym tłem sytuacji wewnętrznej tak w Armenii, jak i w Azerbejdżanie także w czasie wojny w 2020 r. Tym razem było ono wywołane przez nieporadną politykę rządów w Baku i w Erywaniu wobec wyzwania stworzonego przez COVID-19. Walka z pandemią koronawirusa, z powodu wprowadzonych $\mathrm{w}$ jej ramach restrykcji, umożliwiła przy tym zwiększenie inwigilacji opozycji w Azerbejdżanie, a jednocześnie zrodziła potrzebę zwrócenia uwagi społeczeństwa ku innym problemom, wśród których konflikt o Gorski Karabach idealnie pasował do odegrania kluczowej roli ${ }^{165}$. Tocząca się od sierpnia 2020 r. rewolucja na Białorusi ${ }^{166}$ dodatkowo uświadomiła zaś Alijewowi, że bunt ulicy może zagrozić i jego władzy. Zwycięska wojna o utracone, okupowane przez Ormian ziemie, znakomicie służyłaby zaś jej stabilizacji ${ }^{167}$.

Turcja miała podobnie motywy wewnętrzne. Od sierpnia 2018 r. przeżywa problemy gospodarcze $^{168}$ i skierowanie uwagi opinii publicznej na sytuację „bratniego Azerbejdżanu” -

${ }^{162}$ A. Jarosiewicz, M. Falkowski, op.cit. Por.: M. Potocki, Wirusowa wojna zastępcza. Konflikt Armenia Azerbejdżan odwraca uwage od skutków pandemii, „Dziennik. Gazeta Prawna”, 18 lipca 2020, https://www.gazetaprawna.pl/wiadomosci/artykuly/1486416,konflikt-armenia-azerbejdzan-odwraca-uwageskutki-pandemii.html.

${ }^{163}$ P. Мусабеков, op.cit., s.9.

${ }^{164}$ Z. Shiriyev, op.cit., s.14-15.

${ }^{165}$ A. Legieć, Państwa Kaukazu Poludniowego wobec COVID-19, „Biuletyn PISM”, nr 92 (2024), 28 kwietnia 2020, s.2. Patrz też: M. Potocki, op.cit.

${ }^{166}$ O sytuacji na Białorusi w drugiej połowie września 2020 r. patrz: P. Żochowski, Białoruski klincz. Kolejny tydzień protestów, „Analizy OSW”, 21.09.2020, https://www.osw.waw.pl/pl/publikacje/analizy/2020-0921/bialoruski-klincz-kolejny-tydzien-protestow.

167 W. Górecki, Nowa odstona konfliktu o Górski Karabach, „Analizy OSW”, 28.09.2020, https://www.osw.waw.pl/pl/publikacje/analizy/2020-09-28/nowa-odslona-konfliktu-o-gorski-karabach.

${ }_{168}$ M. Chudziak, Marsz linoskoczka. Polityka gospodarcza Turcji w obliczu kryzysu, „Punkt Widzenia OSW”, nr 8223 lutego 2021, ss.47. 
jego wsparcie w konflikcie z Ormianami oraz redukcja wpływów Rosji na Kaukazie wzmocniłyby autorytet Erdoğana, który potrzebował sukcesu. Zwycięstwo Baku, wspartego przez Ankarę w wojnie z Armenią sukces mu taki dostarczało ${ }^{169}$.

Turecki względny zwrot ku Rosji z 2016 r. ${ }^{170}$ wyczerpał swój potencjał korzyści ${ }^{171}$, a wycofanie przez USA poparcia dla Kurdów w 2019 r. ${ }^{172}$ usunęło główne źródło spięć w relacjach Ankara-Waszyngton, pchających Turcję ku Moskwie, nasiliło zatem rywalizację Turków w wyżej wymienionych rejonach (Syria, Libia, Cypr) z tradycyjnym wrogiem Rosją, na dodatek sprzymierzoną z innym tradycyjnym wrogiem - Iranem. Zmuszenie Rosji do „rozciągnięcia linii” poprzez odmrożenie konfliktu o Górski Karabach leżało więc $\mathrm{w}$ interesie Turcji. Ankara udzieliła zatem zdecydowanego poparcia Baku, tak w postaci dostaw broni i instruktorów szkolących armię azerbejdżańską, jak i poprzez rozmieszczenie na terytorium Azerbejdżanu eskadry F-16 i rozpoczęcie wspólnych manewrów tureckoazerskich w Nachiczewaniu z równoczesnym zadeklarowaniem, że w razie wmieszania się w konflikt azersko-ormiański strony trzeciej (w praktyce mogło chodzić tylko o Rosję), Turcja automatycznie stanie się czwartą. W tej sytuacji manewry Flotylli Kaspijskiej w pobliżu Baku i rozmieszczenie rosyjskiej brygady specnazu w Dagestanie na granicy Azerbejdżanu, nie zadziałały odstraszająco na Alijewa ${ }^{173}$.

Armenia wygrawszy wojnę lat 1992-1994 i będąc świadoma swej narastającej słabości wobec Azerbejdżanu była krajem „sytym”. Zagrabiła terytoria sąsiada. Ormianie wiedzieli, że kolejnych nie zdobędą. Ich celem było zatem zachowanie status quo w sensie geograficznym i utrwalenie go $\mathrm{w}$ sensie politycznym poprzez międzynarodowe uznanie niepodległości Górskiego Karabachu, a optymalnie przez aneksję wszystkich zdobytych na

\footnotetext{
${ }^{169}$ Г. Васадзе, op.cit., s.24.

170 Szerzej patrz: M. Chudziak, S. Kardaś, W. Rodkiewicz, Turcja-Rosja: partnerstwo z rozsq̨dku, „Analizy OSW", 12.10.2016, https://www.osw.waw.pl/pl/publikacje/analizy/2016-10-12/turcja-rosja-partnerstwo-zrozsadku.

${ }^{171}$ Przejawy narastających sprzeczności w relacjach turecko-rosyjskich patrz: W. Rodkiewicz, Rosyjsko-tureckie napięcia za parawanem normalizacji, „Analizy OSW”, 15.03.2017, https:/www.osw.waw.pl/pl/publikacje/analizy/2017-03-15/rosyjsko-tureckie-napiecia-za-parawanem-

normalizacji; K. Strachota, M. Marszewski, Rosyjski triumf w Syrii, „Analizy OSW”, 24.10.2019, https://www.osw.waw.pl/pl/publikacje/analizy/2019-10-24/rosyjski-triumf-w-syrii; M. Chudziak, W. Rodkiewicz, Walki w Idlibie: kryzys w stosunkach turecko-rosyjskich, „Analizy OSW”, 26.02.2020, https:/www.osw.waw.pl/pl/publikacje/analizy/2020-02-26/walki-w-idlibie-kryzys-w-stosunkach-tureckorosyjskich.

172 M. Chudziak, Zgoda USA na antykurdyjska operację Turcji w Syrii?, „Analizy OSW”, 9.10.2019, https:/www.osw.waw.pl/pl/publikacje/analizy/2019-10-09/zgoda-usa-na-antykurdyjska-operacje-turcji-w-syrii.

${ }^{173}$ Мусабеков, оp.cit., s.10. Patrz też: Tureckie F-16 „,wsparciem” dla Azerbejdżanu, „Defense24”, 2 sierpnia 2020, https://www.defence24.pl/tureckie-f-16-wsparciem-dla-azerbejdzanu-wideo.
} 
Azerbejdżanie terytoriów do Armenii. Armenia nie miała więc nic do wygrania na wznowieniu walk. Z pewnością nie ona zatem zainicjowała kampanię roku 2020. Jednocześnie jednak przeceniała siły własne i nie doceniała azerbejdżańskich. Nie była w stanie wydawać na zbrojenia tyle co Azerbejdżan, choć w latach 2018-2019 jej wydatki zbrojeniowe sięgały 20\% PKB. Broń kupowano w Rosji, a intensywność rosyjskich dostaw była tak duża, że wywołała aż protesty Azerbejdżanu w już napiętej sytuacji w sierpniu 2020 $\mathrm{r}^{174}$. Wcześniej, obok starego już dziś sprzętu otrzymanego od Rosji w trakcie wojny lat 19921994, dostała od niej kolejny potężny zastrzyk uzbrojenia o wartości ok 1 mld USD, przekazanego Ormianom w latach 2006-2007 z likwidowanej rosyjskiej bazy wojskowej z Achałkalaki w Gruzji, którą Rosja zamknęła ostatecznie 27 czerwca 2007 r. na podstawie porozumienia z Soczi z 2006 r. W kolejnych latach Moskwa wyposażyła swego sojusznika z OUBZ w systemy rakietowe Iskander, a na przełomie lat 2019/2020 - już w trakcie intensywnych zakupów ormiańskich - także w cztery myśliwce przewagi powietrznej Su$30 \mathrm{SM}^{175}$, z perspektywą dalszych dostaw kolejnych ośmiu maszyn tego typu ${ }^{176}$. Pozwalało to ormiańskiej opinii publicznej (żyjącej zrodzonym w wojnie 1992-1994 mitem wyższości żołnierza ormiańskiego nad azerbejdżańskim) wierzyć w przewagę techniczną i organizacyjną własnej armii oraz w przewagę obrońców nad atakującymi, którą w poprzednich wojnach zapewniał górski charakter terenu walk, a zatem odrzucać wszelką myśl o politycznym uregulowaniu konfliktu.

Najwybitniejsi politycy ormiańscy, w tym poważany prezydent Armenii Lewon TerPetrosjan, już w 1997 r. zdali sobie sprawę z przejściowego charakteru przewagi Armenii nad Azerbejdżanem. Sam Ter-Petrosjan usiłował przekonać swych rodaków do polityki ustępstw i porozumienia, został jednak w 1998 r. odsunięty od władzy i zastąpiony przez Roberta Koczariana - przedstawiciela „klanu karabachskiego” reprezentującego nieprzejednaną linię twardej polityki wobec Baku ${ }^{177}$. Mimo to, co najmniej od 2015 r. (od tzw. planu Ławrowa ${ }^{178}$ ) elity ormiańskie zdawały sobie sprawę, że jakaś forma kompromisu może okazać się

\footnotetext{
174 J. Kucera, Aliyev airs grievances to Putin over arms shipments to Armenia, "Eurasianet", Aug 13, 2020, https://eurasianet.org/aliyev-airs-grievances-to-putin-over-arms-shipments-to-armenia. Por.: E. Jafarova, Russian military shipments to Armenia - a dangerous escalation?, "Euractiv", 31 sierpnia 2020, https://www.euractiv.com/section/azerbaijan/opinion/russian-military-shipments-to-armenia-a-dangerousescalation/.

175 P. Мусабеков, ор.cit., s.9. Patrz też: M. Szopa, Su-30SM dla Armenii „Defence24”, 5 listopada 2019, https://www.defence24.pl/su-30sm-dla-armenii.

176 M. Hypś, Armenia chce kolejne Su-30SM, „Konflikty.pl”, 31 sierpnia 2020, https://www.konflikty.pl/aktualnosci/wiadomosci/armenia-chce-kolejne-su-30sm/. Por.: Г. Васадзe, op.cit., s.23.

177 T. Świętochowski, Azerbejdżan..., s.176-179. Por.: Z. Rokita, op.cit., s.141.

${ }_{178}$ P.A. Świtalski, Armeńska rewolucja, Warszawa, 2020, s.115-116. Por.: Г. Васадзе, op.cit., s.23.
} 
niezbędna. Po porażce w „wojnie czterodniowej” w 2016 r. świadomość ta wyraźnie narastała, ale nie przyniosło to konkretów w relacjach z Baku ${ }^{179}$. Dodatkowo sytuację Ormian pogarszał fakt praktycznej izolacji geograficznej Armenii od Rosji. Państwo to bowiem, pozbawione dostępu do morza i otoczone przez wrogie jej Turcję i Azerbejdżan oraz skonfliktowaną z Rosją Gruzję, mogło być zaopatrywane przez Rosję wyłącznie drogą przez Morze Kaspijskie i Iran, co ani politycznie (Azerów jest w Iranie więcej niż w Azerbejdżanie), ani logistycznie, nie odpowiadało potrzebom wojennym ${ }^{180}$.

Tymczasem nie tylko sytuacja wojskowa zmieniała się na niekorzyść Armenii. Pomysł czerpania korzyści jednocześnie z sojuszu z Rosją i ze zbliżenia z Unią Europejską okazał się niewykonalny. W 2013 r. Armenia, należąca do Partnerstwa Wschodniego ${ }^{181}$, stanęła wobec konieczności określenia się $\mathrm{W}$ stosunku do rosyjskiego projektu Eurazjatyckiej Unii Gospodarczej (wówczas jeszcze formalnie nadal Unii Celnej). Pogodzenie obu kierunków integracji było niemożliwe i Erywań ostatecznie wybrał Moskwę, dystansując się od UE ${ }^{182}$. W 2018 r. ostudziły się natomiast także relacje Armenii z Rosją. Rewolucja, która wówczas odsunęła od władzy w Armenii lojalny wobec Kremla „klan karabachski” i wyniosła do władzy Nikola Paszyniana ${ }^{183}$, wprowadziła nieufność między Moskwą a Erywaniem ${ }^{184}$. Armenia wciśnięta między Azerbejdżan i Turcję, z pamięcią o ludobójstwie Ormian z lat 1915-1917, jest jednak jedynym szczerym sojusznikiem Rosji na Kaukazie. Mit groźby powtórzenia eksterminacji narodu gra tę rolę, którą gra w Izraelu pamięć o Holocauście. Ktokolwiek zatem będzie rządził w Erywaniu i jakkolwiek będzie wobec Ormian zachowywała się Moskwa (lojalnie czy też nie), są oni skazani na sojusz z Kremlem. Innej siły zdolnej do interwencji wojskowej po stronie Ormian nie ma i nie będzie. Paszynian pod dojściu do władzy demonstrował więc wierność Armenii wobec sojuszu z Rosją. Wysłał niewielki kontyngent wojsk armeńskich do Syrii do działań u boku Rosji, zezwolił na rosyjskie inspekcje w laboratoriach bakteriologicznych w Armenii, działających przy

\footnotetext{
179 P.A. Świtalski, op.cit., s.115-120.

${ }^{180}$ P. Мусабеков, op.cit., s.10.

${ }^{181}$ Szerzej o Partnerstwie Wschodnim patrz: P. Żurawski vel Grajewski, op.cit., s.260-290.

182 P.A. Świtalski, op.cit., s.130-136.

${ }^{183}$ Szerzej patrz: P.A. Świtalski, op.cit., s.33-114. Por.: W. Górecki, Armenia: zwycięstwo bloku Paszyniana, „Analizy OSW", 10.12.2018, https://www.osw.waw.pl/pl/publikacje/analizy/2018-12-10/armenia-zwyciestwobloku-paszyniana. Por.: J. Benedyczak, Wybory parlamentarne w Armenii: Polityczna (r)ewolucja i nadzieja zmian, „Komentarz PISM”, $11 \quad$ grudnia 2018 , https://www.pism.pl/publikacje/Wybory_parlamentarne_w_Armenii_Polityczna_rewolucja_i_nadzieja_zmian. ${ }^{184}$ O stosunku Rosji do owej rewolucji patrz: W. Górecki, J. Strzelecki, Rewolucja na raty. Dokąd zmierza Armenia Paszyniana?, „Komentarze OSW”, nr 285, 10.09.2018, s.1, 7-8 oraz W. Górecki, Armenia: nowa runda konfliktu politycznego, „Analizy OSW”, 22.0.2019, https://www.osw.waw.pl/pl/publikacje/analizy/2019-0522/armenia-nowa-runda-konfliktu-politycznego.
} 
wsparciu z USA i podpisał wyżej wspomniane kontrakty na dostawy rosyjskiego uzbrojenia $^{185}$. Usiłował to potem zdyskontować politycznie - już w czasie trwania kampanii roku 2020 co najmniej dwukrotnie zwracał się do Putina z prośbą o wsparcie ${ }^{186} \mathrm{z}$ bardzo umiarkowanym skutkiem.

Zwycięstwo rewolucji Paszyniana w Armenii wpłynęło także, choć w sposób odłożony w czasie, na decyzję Azerbejdżanu o odwołaniu się do rozstrzygnięć wojskowych. Odsunięcie od władzy w Erywaniu „klanu karabachskiego”, zdeterminowanego utrzymać w ormiańskim ręku zdobycze wojenne z lat 1992-1994, wzbudziło początkowo nadzieję w Baku na postęp rokowań i dyplomatyczne rozwiązanie sporu. Wobec zapatrzonej w mit swej potęgi wojskowej ormiańskiej opinii publicznej nowa - porewolucyjna władza Armenii nie była jednak w stanie dokonać żadnych koncesji na rzecz Azerbejdżanu ${ }^{187}$. Rozbudzone nadzieje Azerów, szybko więc zmieniły się w gorzkie rozczarowanie, ono zaś w decyzję o zbrojnym odzyskaniu zagrabionych ziem.

Rosja została zaskoczona eskalacją konfliktu, która utrudnia jej kontrolę nad obiema zwaśnionymi stronami. Dotąd sprzedawała broń tak Azerom, jak i Ormianom i tanim kosztem umacniała swe wpływy w obu państwach, zmuszając je do zabiegania o swe poparcie w obawie, by nie udzieliła go konkurentowi. Ofensywa azerska złamała ten system rosyjskiego panowania.

Moskwa formalnie zobowiązana jest do pomocy Armenii jako sojusznikowi z OUBZ, ale układ ten nie obejmuje Górskiego Karabachu i okupowanych przez Ormian terenów azerskich, które wszak w sensie prawnym nie są częścią Armenii. Putin nie omieszkał skorzystać z tego faktu i publicznie przypomniał to Ormianom już w czasie trwania azerskiej ofensywy ${ }^{188}$. Stanowisko to oficjalnie potwierdził 23 października 2020 r. wiceminister spraw zagranicznych Rosji Aleksandr Pankin ${ }^{189}$. W Armenii właściwej walki się nie toczyły. (Doniesienia $\mathrm{z}$ frontu są narzędziem wojny propagandowej obu stron i jako takie były mało wiarygodne. Wojska azerskie $\mathrm{z}$ pewnością jednak nie wkroczyły nigdzie na terytorium

\footnotetext{
185 P.A. Świtalski, op.cit., s.139.

186 Paszynian zwrócit się do Kremla z prośba o wsparcie, portal Studium Europy Wschodniej Uniwersytetu Warszawskiego, 5.11.2020, https://studium.uw.edu.pl/paszynian-zwrocil-sie-do-kremla-z-prosba-o-wsparcie/

${ }^{187}$ P.A. Świtalski, op.cit., s.115, 118-120.

188 Russia's Security Guarantees for Armenia Don't Extend to Karabakh, Putin Says, "The Moscow Times", October 7, 2020, https://www.themoscowtimes.com/2020/10/07/russias-security-guarantees-for-armenia-dontextend-to-karabakh-putin-says-a71687.

${ }^{189}$ K. Chawryło, Rosja wobec konfliktu w Górskim Karabachu: wykalkulowana neutralność, „Analizy OSW”, 26.10.2020, https://www.osw.waw.pl/pl/publikacje/analizy/2020-10-26/rosja-wobec-konfliktu-w-gorskimkarabachu-wykalkulowana-neutralnosc.
} 
Armenii). Kreml zaangażowany wojskowo na Ukrainie, w Syrii, nieformalnie w Libii (po przeciwnej stronie niż Turcja, ale po tej samej co Francja) i zagrożony problemami na Białorusi i w Kirgistanie, nie pragnął zaś otwierania nowego frontu na Kaukazie. Rosja ciężko dotknięta kryzysem na rynku ropy naftowej i gazu ziemnego, mająca poważne problemy wizerunkowe na Zachodzie po otruciu Nawalnego, walcząca o utrzymanie projektu Nord Stream 2, nie chciała płacić zwiększonych kosztów swej dominacji na Kaukazie. Szybka pacyfikacja konfliktu i powrót do stanu sprzed 27 września lub zbliżonego leżały więc w jej interesie, podobnie jak w interesie Armenii. Akcja zbrojna Azerbejdżanu, wspieranego materiałowo i politycznie przez Turcję, zburzyła jednak te kalkulacje moskiewskie, jeśli istotnie szły one w tym kierunku. Podejmowane przez Rosję od początku wybuchu intensywnych walk inicjatywy rozejmowe długo były bowiem nieskuteczne. Przyjęte 10 i 17 października pod wpływem Kremla doraźne porozumienia o zawieszeniu broni nie weszły w życie. Bezowocne okazały się też wizyty ministrów spraw zagranicznych Armenii Zohraba Mnacakaniana i Azerbejdżanu Dżejhuna Bajramowa w Moskwie 20 i 21 października 2020 r. (Nawiasem mówiąc - nie tylko Rosji nie wiodła się rola mediatora. Ich spotkania z sekretarzem stanu USA Mikiem Pompeo w Waszyngtonie 23 października, także nie przyniosły rozejmu ${ }^{190}$ ). 14 października minister spraw zagranicznych Rosji Siergiej Ławrow zapowiedział, że możliwe jest wprowadzenie do strefy konfliktu rosyjskiej misji pokojowej w postaci obserwatorów wojskowych, o ile zgodzą się na to obie walczące strony. Erywań poparł tę propozycję, ale Azerbejdżan, którego wojska w zwycięskiej ofensywie z każdym dniem powiększały kontrolowany przez siebie obszar, nie miał powodu, by ją zaakceptować $^{191}$. Rosja nie chciała angażować się w konflikt, antagonizując Azerbejdżan i Turcję, ze względów prestiżowych nie mogła jednak dopuścić do zupełnej klęski Armenii. Dalsza eskalacja (zagrożenie przez ofensywę azerbejdżańską Stepanakertu lub terytorium Armenii właściwej) zdecydowanie nie leżały więc w interesie Moskwy. Rosja musiałaby albo wystąpić zbrojnie po stronie Armenii i zapłacić tego koszty finansowe i polityczne w relacjach z Azerbejdżanem, Turcją i Zachodem, albo podważyć swą wiarygodność jako hegemon OUBZ, przez opuszczenie sojuszniczej Armenii. Ostatecznie doprowadziła więc do rozejmu z 9/10 listopada, ale mogła to uczynić nie wcześniej, jak tylko w chwili, gdy skala zdobyczy Azerbejdżanu, uzyskanych w wyniku działań wojennych, pozwalała władzom w

\footnotetext{
${ }^{190}$ Szefowie MSZ Armenii i Azerbejdżanu spotkaja się w Waszyngtonie, portal Studium Europy Wschodniej Uniwersytetu Warszawskiego, 22.10.2020, https://studium.uw.edu.pl/szefowie-msz-armenii-i-azerbejdzanuspotkaja-sie-w-waszyngtonie/.

191 K. Chawryło, op.cit.
} 
Baku przyjąć mediację rosyjską, nie rezygnując ze statusu oczywistego zwycięzcy. To Rosja musiała więc starać się o korzystną dla siebie decyzję Azerbejdżanu (i Turcji) i czekać na dogodny dla niej moment, by ją uzyskać, a nie odwrotnie. Oczywiście mogłaby ją wymusić wcześniej, ale ponosząc koszty, których ponieść nie chciała. Konstatacja tego faktu upoważnia do wniosku, że tania dominacja rosyjska na Kaukazie dobiegła końca.

Iran jako kolejny tradycyjnie ważny gracz w regionie, mając liczącą ponad $20 \mathrm{mln}$ ludzi mniejszość azerską we własnym państwie, w chwili wybuchu walk formalnie poparł Azerbejdżan, a przywódca duchowy Iranu ogłosił wszystkich poległych w tej wojnie żołnierzy azerbejdżańskich szahidami (tzn. męczennikami za wiarę). W praktyce jednak Teheran, powiązany współpracą z Rosją i oddzielony tradycyjną wrogością od Turcji, a także świadom, że nie ma szansy na dyplomatyczny udział w rozwiązywaniu konfliktu, zachowywał się powściągliwie ${ }^{192}$.

\section{Wynik starcia - wnioski}

Konflikt o Górski Karabach w relacjach azerbejdżańsko-rosyjskich nigdy nie zajmował tak centralnej roli jak w relacjach rosyjsko-ormiańskich. Znacznie mocniej uzależniał on bowiem od Rosji Ormian niż Azerów ${ }^{193}$. Przebieg wydarzeń z jesieni $2020 \mathrm{r}^{194}$. potwierdził tę tezę. Wojna została wygrana przez sojusznika Turcji, a przegrana przez sojusznika Rosji. Sojusz z Rosją i to formalny - potwierdzony traktatami, okazał się nie chronić przed klęską. Fakt, że układ sojuszniczy nie obejmował odpowiedzialnością traktatową obszaru, na którym toczyły się walki, dla odbioru społecznego ma drugorzędne znaczenie. Sam sojusz był zaś świeżo zademonstrowany wspomnianym wysłaniem do Syrii armeńskiego kontyngentu wojskowego do wspólnych operacji z Rosją. Ormianie są więc zawiedzeni. W tym sensie psychologicznie kampania jesienna 2020 r. jest odwrotnością sytuacji z 2008 r., gdy to najazd rosyjski na Gruzję wykazał narodom kaukaskim, że orientacja na Stany Zjednoczone, mimo gruzińskiego kontyngentu wojskowego w Iraku, nie daje osłony - nie jest ,prawdziwym sojuszem”.

Wynik starcia - postanowienia rozejmu z 9/10 listopada 2020 r. nie mają jednoznacznej oceny. Wszystkie okupowane od 26 lat tereny leżące wokół właściwego

\footnotetext{
${ }^{192}$ Г. Васадзе, op.cit., s.25.

193 Ibidem s.23.

194 O samej kampanii 2020 r. patrz: W. Górecki, Nowa odsłona konfliktu o Górski Karabach, „Analizy OSW”, 28.09.2020, https://www.osw.waw.pl/pl/publikacje/analizy/2020-09-28/nowa-odslona-konfliktu-o-gorskikarabach,
} 
Górskiego Karabachu (z wyjątkiem korytarza laczyńskiego) oraz jego południowa część wraz z Szuszą wróciły pod władzę Azerbejdżanu, natomiast część północna dawnego GKOA ze stołecznym Stepanakertem i korytarzem laczyńskim jako łącznikiem z Armenią pozostały pod kontrolą ormiańską, bez decyzji co do ich przyszłego statusu ${ }^{195}$. Poza oczywistym sukcesem Azerbejdżanu i klęską Armenii odpowiedź na pytanie o wpływ ormiańsko-azerskiej kampanii jesiennej 2020 r. na pozycję Rosji i Turcji w regionie nie jest już tak jednoznaczna. Część komentatorów uznała skutki tego etapu wojny za strategiczny sukces Rosji, która bez własnego zaangażowania wojskowego uchroniła Armenię przed jeszcze głębszą klęską, zachwiała nielubianym w Moskwie rządem Paszyniana i na dodatek wprowadziła swe wojska w charakterze „sił pokojowych" do Górskiego Karabachu i do korytarza łączącego Azerbejdżan z Nachiczewaniem, gdzie ich poprzednio nie było ${ }^{196}$. To ważkie argumenty. Są jednak i poważne kontrargumenty przeciw uznaniu osiągniętego rezultatu wojny za sukces Rosji.

Moskwa nie życzyła sobie wybuchu walk i nie mogąc mu zapobiec, reagowała improwizując. Unikając kosztownego dla niej bezpośredniego zaangażowania wojskowego, grożącego co najmniej nasileniem rywalizacji z Turcją, z którą już dochodziło do serii starć pośrednich lub nieoficjalnych w Syrii i w Libii, nie zawsze dla Rosji pomyślnych, nie uchroniła Armenii od klęski, ale też i zapobiegła temu, by stała się ona całkowita. Została zmuszona do wpuszczenia wpływów tureckich na obszar dotąd absolutnie zmonopolizowany przez Moskwę, ale - z drugiej strony - przynajmniej traktatowo - na mocy rozejmu, ograniczyła ich dalsze rozprzestrzenianie się (Pytanie na ile w praktyce skutecznie?) ${ }^{197}$. „Postawienie butów”, czyli rozmieszczenie rosyjskich wojsk w rejonach, gdzie ich dotąd nie było może być sukcesem pozornym - raczej prestiżowym niż rzeczywistym. Wszak wszystkie kluczowe rejony (korytarz lacziński, szlak Azerbejdżan- Nchiczewań) Rosja kontrolowała dotąd pośrednio - przez sprzymierzonych z nią Ormian, którzy nie byli w dobrej pozycji, by odmawiać wykonania jakichkolwiek rosyjskich życzeń odnośnie do uczynienia użytku z tej kontroli. Czynili to jednak na własny koszt i na własne ryzyko.

\footnotetext{
195 W. Górecki, Górski Karabach: kapitulacja Armenii, sukces Rosji, „Analizy OSW”, 10.11.2020, https://www.osw.waw.pl/pl/publikacje/analizy/2020-11-10/gorski-karabach-kapitulacja-armenii-sukces-rosji.

${ }^{196}$ W. Górecki, Górski Karabach: kapitulacja Armenii, .... Por.: M. Dura, Pokój za obce wojska. Rosyjska armia w Górskim Karabachu, „Defence24”, 22 listopada 2020, https://www.defence24.pl/pokoj-za-obce-wojskarosyjska-armia-w-gorskim-karabachu-, oraz Rosyjskie „,sity pokojowe” w Karabachu, „Warsaw Institute”, 12 listopada 2020, https://warsawinstitute.org/pl/rosyjskie-sily-pokojowe-w-karabachu/.

197 L. Broers, Perspectives. Did Russia win the Karabakh war?, "Eurasianet", November 17, 2020, https://eurasianet.org/perspectives-did-russia-win-the-karabakh-war
} 
Obecnie koszty te przejęła Rosja - prawda, że co do kosztów finansowych - niewielkie zważywszy na liczebność kontyngentu pokojowego (ok. 1960 żołnierzy, 90 transporterów opancerzonych BTR-82A, 380 samochodów i sprzętu specjalnego plus funkcjonariusze pochodzących spoza resortu obrony), ale jednak zawsze większe niż dotąd. ${ }^{198}$ Koszty polityczne mogą okazać się znacznie dotkliwsze. Utrzymanie statusu Federacji Rosyjskiej jako „przyjaznego mocarstwa” wobec obu stron konfliktu, przy bezpośredniej obecności wojskowej w terenie może być dla Kremla znacznie trudniejsze niż dotąd. Wszystkie te korzyści Rosji nie przesłaniają jednak faktu, że w sensie strategicznym, to wola polityczna Azerbejdżanu i Turcji, a nie Moskwy została przeprowadzona, a układ sił w regionie zrewidowany nie na mocy decyzji Kremla, lecz Baku i Ankary. Rosja poważnie oddziaływała na kierunek i skalę tej rewizji, ale to nie jej plan był wykonywany, nie ona inicjowała bieg wydarzeń, a jedynie na nie reagowała. Rosja wyraźnie zademonstrowała też niechęć do bycia uwikłaną w tę wojnę, co odbierane jest jako oznaka jej słabości. W dniu rozejmu - 10 listopada 2020 r. doszło do zestrzelenia - oficjalnie przez siły azerbejdżańskie (a ponieważ dokonano tego rakietą turecką $\mathrm{z}$ terytorium Nachiczewania, nie można wykluczyć, że $\mathrm{w}$ istocie przez siły tureckie) rosyjskiego śmigłowca Mi-24, lecącego w przestrzeni powietrznej Armenii, eskortującego konwój rosyjski, zmierzający do 102 Bazy w Giumri. Zginęło dwóch członków załogi. Reakcja Moskwy swą łagodnością drastycznie odbiegała od tej po zestrzeleniu przez Turków rosyjskiego Su-24 w listopadzie 2015 r. Tym razem szybko przyjęto przeprosiny Baku i incydent zażegnano ${ }^{199}$.

Rosja utraciła monopol inicjowania rozstrzygnięć zbrojnych na obszarze byłego ZSRR. Dotąd była jedynym podmiotem, który w tej przestrzeni geopolitycznej rozpoczynał wojny i je wygrywał. Teraz dokonał tego Azerbejdżan i to z pomocą turecką, zadając klęskę sojusznikowi Rosji. Straty prestiżowe Kremla w regionie są więc poważne.

Uwagę zwraca prawie absolutna nieobecność Zachodu w toczącej się rozgrywce. Zaaferowane kampanią prezydencką Stany Zjednoczone nie angażowały się w konflikt, poza mającymi $\mathrm{w}$ istocie charakter wyborczy deklaracjami walczących kandydatów skierowanymi do diaspory ormiańskiej w USA. Unia Europejska nie wyszła poza standardowe wezwania do

\footnotetext{
198 M. Dura, Rosjanie rozkładaja się w Górskim Karabachu. Powtórka z Naddniestrza?, "Defence24", 17 listopada 2020, https:/www.defence24.pl/rosjanie-rozkladaja-sie-gorskim-karabachu-powtorka-z-naddniestrza. ${ }^{199}$ M. Galeotti, Russian Ceasefire Deal in Nagorno-Karabakh Marks Slow, Painful End of Empire in the South Caucasus, "The Moscow Times", November 10, 2020, https://www.themoscowtimes.com/2020/11/10/russianceasefire-deal-marks-slow-painful-end-of-empire-in-the-south-caucasus-a72001.
} 
deeskalacji i poszukiwań pokojowego rozwiązania sporu ${ }^{200}$, a jej rola na Kaukazie uległa kompletnej marginalizacji ${ }^{201}$. Francja, posiadająca wpływową diasporę ormiańską, ustami prezydenta Macrona silnie poparła Armenię, ale nic poza retoryką nie była w stanie jej zaoferować 202 .

$\mathrm{Na}$ zakończenie niniejszych rozważań, rozwiejmy kilka mitów funkcjonujących na temat omawianego konfliktu.

Kto jest agresorem? Azerbejdżan zapewne za wiedzą, a może i inspiracją turecką podjął próbę odzyskania kontroli nad swoim terytorium, do której ma prawo, potwierdzone czterema rezolucjami Rady Bezpieczeństwa ONZ z 1993 r $^{203}$. i Rezolucją Zgromadzenia Ogólnego ONZ z 2008 r $^{204}$. Wojska azerbejdżańskie w żadnym momencie nie operowały na terytorium Armenii, przeciwnie działały wyłącznie na obszarze prawnie uznawanym przez wszystkie państwa świata (oczywiście z wyjątkiem Armenii) za część Azerbejdżanu. W tej sytuacji sformułowania o azerskiej agresji są nie na miejscu. Ukraina odbijając Donbas i Krym nie dokonywałaby wszak agresji na Rosję, tylko wyzwalałaby swe terytoria.

Ormianom nie grozi eksterminacja. Azerbejdżan z uwagi na stanowisko Rosji nie był w stanie podbić Armenii, a zapewne nawet zdobyć Stepanakertu. Konflikt zakończył się więc w momencie, gdy Alijew uznał, że zdobycze terytorialne są dostatecznie duże, by usatysfakcjonować azerską opinię publiczną, a jemu dać wieniec zwycięzcy, zatrzymując

200 EU voices 'extreme concern' over Nagorno-Karabakh breaches, "Deutsche Welle", 11.10.2020, https:/www.dw.com/en/eu-voices-extreme-concern-over-nagorno-karabakh-breaches/a-55237607

201 N. Popescu, How the EU became marginalised in Nagorno-Karabakh, "European Council on Foreign $\begin{array}{llll}\text { Relations } & \text { ecfr.eu", } & \text { October } & 2020 \text {, }\end{array}$ https://ecfr.eu/article/commentary_how_europe_became_marginalised_in_nagorno_karabakh/.

${ }^{202}$ Г. Васадзе, op.cit., s.25.

203 W 1993 r. Rada Bezpieczeństwa ONZ przyjęła następujące rezolucje potwierdzające suwerenność Azerbejdżanu nad Górskim Karabachem i wzywające Armenię do powstrzymanie agresji na jego terytorium: Resolution 822 (1993) / adopted by the Security Council at its 3205th meeting, on 30 April 1993, United Nations Digital Library, https://digitallibrary.un.org/record/165604; Resolution 853 (1993) / adopted by the Security Council at its 3259th meeting, on 29 July 1993, United Nations Digital Library, https://digitallibrary.un.org/record/170257; Resolution 874 (1993) / adopted by the Security Council at its 3292nd meeting, on 14 October 1993, United Nations Digital Library, https://digitallibrary.un.org/record/174420; Resolution 884 (1993) / adopted by the Security Council at its 3313th meeting, on 12 November 1993, United Nations Digital Library, https://digitallibrary.un.org/record/176731. Por.: 1993 UN Security Council Resolutions on Nagorno-Karabakh, U.S. Department of State, Archive, Information released online from January 20, 2001 to January 20, 2009, https://20012009.state.gov/p/eur/rls/or/13508.htm\#822.

${ }^{204}$ General Assembly Adopts Resolution Reaffirming Territorial Integrity of Azerbaijan, Demanding Withdrawal of All Armenian Forces, GA/10693, 14 March 2008, General Assembly, Plenary, United Nations Meetings Coverage and Press Releases, https://www.un.org/press/en/2008/ga10693.doc.htm. 
operację poniżej progu otwartej konfrontacji z Rosją, do której z wysokim prawdopodobieństwem wiódłby scenariusz zupełnego rozgromienia Armenii.

To nie jest wojna wyznaniowa Konflikt o Górski Karabach ma charakter etniczny, nie wyznaniowy. Azerowie są wprawdzie muzułmanami, ale po 70 latach narzuconego przez Moskwę komunizmu bardzo umiarkowanymi. Są w większości szyitami, wspieranymi przez sunnickich Turków jako „etniczni krewni”, a nie jako „bracia w wierze”. Wszędzie indziej sunnici i szyici zabijają się bezlitośnie, czego Syria i Irak są bieżącymi przykładami.

„Sprawiedliwość dziejowa” nie może być rozsądnym celem polityki zagranicznej żadnego państwa. Ormianie byli na Kaukazie „od zawsze”. Turcy i Azerowie przybyli tam w X-XI w. i do XX w. zagarnęli spore części historycznej Armenii. Nic z tego dla obecnej polityki nie wynika, chyba, że logicznie uznamy, że Anglosasi powinni zostawić Anglię Walijczykom, a sami powrócić na Jutlandię, bo stamtąd przybyli. Prawdą jest, że granice Azerbejdżańskiej SRS i Armeńskiej SRS wyznaczone zostały przez Stalina. Z tego jednak także nic obecnie dla rozsądnie prowadzonej polityki nie wynika. Stalin zdecydował wszak o granicach w Europie od Finlandii po Armenię, Polski nie wykluczając. Mogą się one nie podobać, ale jedyną metodą ich przesuwania jest wojna. Ormianie zdecydowali się na tę metodę w latach 19921994 i jesienią 2020 r. zapłacili tego cenę. Orężnie zajęli sporne ziemie i od oręża znaczną ich część utracili, przy czym raczej „strategiczną otulinę” etnicznie ormiańskiego Górskiego Karabachu niż sam zasadniczy przedmiot konfliktu, czyli właściwy Górski Karabach, który w lwiej części pozostał pod ich kontrolą.

\section{Streszczenie:}

Prezentowany artykuł jest analizą wydarzeń wiodących do kampanii jesiennej roku 2020, będącej ostatnim jak dotąd etapem toczonej ze zmiennym natężeniem od 1992 r. wojny azersko-ormiańskiej o Górski Karabach i przyległe doń tereny. Oglądowi poddano przyczyny konfliktu i sytuację w jakiej znalazły się zarówno Armenia, jak i Azerbejdżan w wyniku podjęcia w latach 1987-1994 zbrojnego sporu o rzeczoną prowincję. Przedstawiono też ewolucję układu sił w regionie konfliktu - stanowiska i zmianę potencjału jego stron oraz polityki mocarstw je wspierających (Rosji i Turcji), aż po ponowny wybuch intensywnych walk jesienią $2020 \mathrm{r}$. Starano się zidentyfikować motywy postępowania czterech głównych aktorów opisywanych wydarzeń: Armenii, Azerbejdżanu, Rosji i Turcji. W tekście podjęta została także próba oceny osiągniętego rezultatu. Całość wywodu wiedzie do wniosków o relatywnym osłabnięciu pozycji i prestiżu Rosji w regionie, której sojusznik - Armenia poniósł zdecydowaną klęskę przy bierności Moskwy, wzroście prestiżu i znaczenia Turcji, której sojusznik - Azerbejdżan odniósł zwycięstwo, zachowaniu przez Rosję lwiej części wpływów w regionie, ale $\mathrm{z}$ utratą monopolu na wszczynanie konfliktów zbrojnych na obszarze postsowieckim i wygrywania ich. Ważną konkluzją jest także stwierdzenie 
absolutnej marginalizacji oddziaływania Zachodu na przebieg wydarzeń i zapadłe rozstrzygnięcie. Wpływ tak UE jak i USA na bieg spraw na Kaukazie w trakcie kampanii roku 2020 był bowiem niedostrzegalny.

\section{Słowa kluczowe:}

Armenia, Azerbejdżan, Górski Karabach, Rosja, Turcja, wojna.

\section{Key words:}

Armenia, Azerbaijan, Nagorno-Karabakh, Russia, Turkey, war

\section{Bibliografia:}

1. 1993 UN Security Council Resolutions on Nagorno-Karabakh, U.S. Department of State, Archive, Information released online from January 20, 2001 to January 20, 2009, https://2001-2009.state.gov/p/eur/rls/or/13508.htm\#822 (15.04.2021)

2. Armenia i Azerbejdżan - czyja armia jest silniejsza?, „Kresy24.pl”, https://kresy24.pl/armenia-i-azerbejdzan-czyja-armia-jest-silniejsza/ (23.05.2021)

3. Azerbejdżan się zbroi, "Analizy OSW”, https://www.osw.waw.pl/pl/publikacje/analizy/2010-10-27/azerbejdzan-sie-zbroi (23.05.2021)

4. Bartuzi W., Gruziński kocioł między Abchazją, Osetią południową a Adżarią 19912006, [w:] P. Ostaszewski (red.), Konflikty kolonialne i postkolonialne w Afryce i Azji 1869-2006, Warszawa 2006,

5. Bekdil B.E., Azerbaijan to buy armed drones from Turkey, "Defense News", June 25, 2020, https://www.defensenews.com/unmanned/2020/06/25/azerbaijan-to-buy-armeddrones-from-turkey/ (24.03.2021)

6. Benedyczak J., Wybory parlamentarne w Armenii: Polityczna (r)ewolucja i nadzieja zmian, „Komentarz PISM”, 11 grudnia 2018, https://www.pism.pl/publikacje/Wybory_parlamentarne_w_Armenii_Polityczna_rewo lucja_i_nadzieja_zmian. (24.03.2021)

7. Bloodshed in the Caucasus. Escalation of the Armed Conflict in Nagorno-Karabakh, Human Rights Watch / Helsinki (former Helsinki Watch),

8. Broers L., Perspectives. Did Russia win the Karabakh war?, "Eurasianet", https://eurasianet.org/perspectives-did-russia-win-the-karabakh-war (24.03.2021)

9. Chawryło K., Rosja wobec konfliktu w Górskim Karabachu: wykalkulowana neutralność, „Analizy OSW”, https://www.osw.waw.pl/pl/publikacje/analizy/2020-1026/rosja-wobec-konfliktu-w-gorskim-karabachu-wykalkulowana-neutralnosc (25.04.2021)

10. Chudziak M., Kardaś S., Rodkiewicz W., Turcja-Rosja: partnerstwo z rozsądku, „Analizy OSW”, https://www.osw.waw.pl/pl/publikacje/analizy/2016-10-12/turcjarosja-partnerstwo-z-rozsadku (14.04.2021) 
11. Chudziak M., Marsz linoskoczka. Polityka gospodarcza Turcji w obliczu kryzysu, „Punkt Widzenia OSW”, nr 8223 lutego 2021

12. Chudziak M., Rodkiewicz W., Walki w Idlibie: kryzys w stosunkach tureckorosyjskich, „Analizy OSW”, https://www.osw.waw.pl/pl/publikacje/analizy/2020-0226/walki-w-idlibie-kryzys-w-stosunkach-turecko-rosyjskich (4.04.2021)

13. Chudziak M., Zgoda USA na antykurdyjską operację Turcji w Syrii?, „Analizy OSW", https://www.osw.waw.pl/pl/publikacje/analizy/2019-10-09/zgoda-usa-naantykurdyjska-operacje-turcji-w-syrii (24.05.2021)

14. Czachor R., Dynamika inicjatyw międzynarodowych na rzecz regulacji konfliktu w Górskim Karabachu, „Zeszyty Naukowe Wyższej Szkoły Oficerskiej Wojsk Lądowych", nr 3 (173)/2014.

15. Darski J., Rumunia. Historia, współczesność, konflikty narodowe, Warszawa 1993,

16. Dura M., Pokój za obce wojska. Rosyjska armia w Górskim Karabachu, „Defence24”, https://www.defence24.pl/pokoj-za-obce-wojska-rosyjska-armia-w-gorskimkarabachu- (23.05.2021)

17. Dura M., Rosjanie rozkładają się w Górskim Karabachu. Powtórka z Naddniestrza?, "Defence24", https://www.defence24.pl/rosjanie-rozkladaja-sie-gorskim-karabachupowtorka-z-naddniestrza (14.06.2021)

18. Dyner A. M., Legieć A., Wojskowy wymiar konfliktu o Górski Karabach, „Biuletyn PISM", NR 241 (2173)/2020.

19. Dyner A. M., Zasztowt K., Eskalacja konfliktu w Górskim Karabachu - przyczyny i prawdopodobny dalszy przebieg, ,Biuletyn PISM”, nr 26 (1376)/2016.

20. Dyner A. M., Znaczenie zagranicznych baz wojskowych dla Rosji, „Biuletyn PISM”, nr $112(2044) / 2020$.

21. Eberhardt A., Armed Conflicts in Georgia: the Russian Factor, [w:] A. Eberhardt i A. Iwashita (red.), Security Challenges in the Post-Soviet Space. European and Asian Perspectives, Warszawa-Sapporo 2007

22. EU voices 'extreme concern' over Nagorno-Karabakh breaches, "Deutsche Welle", https://www.dw.com/en/eu-voices-extreme-concern-over-nagorno-karabakhbreaches/a-55237607 (02.03.2021)

23. Falkowski M., Polityka Rosji na Kaukazie Południowym i w Azji Centralnej / Russia's policy in the Southern Caucasus and Central Asia, „Prace OSW”, nr 23, Warszawa czerwiec 2006 / Warsaw June 2006

24. Galeotti M., Russian Ceasefire Deal in Nagorno-Karabakh Marks Slow, Painful End of Empire in the South Caucasus, "The Moscow Times", https://www.themoscowtimes.com/2020/11/10/russian-ceasefire-deal-marks-slowpainful-end-of-empire-in-the-south-caucasus-a72001 (12.03.2021)

25. General Assembly Adopts Resolution Reaffirming Territorial Integrity of Azerbaijan, Demanding Withdrawal of All Armenian Forces, GA/10693, 14 March 2008, General Assembly, Plenary, United Nations Meetings Coverage and Press Releases, https://www.un.org/press/en/2008/ga10693.doc.htm. (11.04.2021)

26. Geukijan O., Ethnicity, Nationalism and Conflict in the South Caucasus. NagornoKarabakh and the Legacy of Soviet Nationality Policy, Ashgate 2012. 
27. Górecki W., Armenia: nowa runda konfliktu politycznego, „Analizy OSW”, https://www.osw.waw.pl/pl/publikacje/analizy/2019-05-22/armenia-nowa-rundakonfliktu-politycznego (11.04.2021)

28. Górecki W., Armenia: zwycięstwo bloku Paszyniana, „Analizy OSW”, https://www.osw.waw.pl/pl/publikacje/analizy/2018-12-10/armenia-zwyciestwobloku-paszyniana. (13.03.2021)

29. Górecki W., Górski Karabach: kapitulacja Armenii, sukces Rosji, „Analizy OSW”, https://www.osw.waw.pl/pl/publikacje/analizy/2020-11-10/gorski-karabach-

kapitulacja-armenii-sukces-rosji (11.04.2021)

30. Górecki W., Kaukaski węzeł gordyjski. Konflikt o Górski Karabach, „Raport OSW”, $5 / 2020$

31. Górecki W., Nowa odsłona konfliktu o Górski Karabach, „Analizy OSW”, https://www.osw.waw.pl/pl/publikacje/analizy/2020-09-28/nowa-odslona-konfliktu-ogorski-karabach (11.04.2021)

32. Górecki W., Strzelecki J., Rewolucja na raty. Dokąd zmierza Armenia Paszyniana?, „Komentarze OSW”, nr 285/2018.

33. Gusejnow R., Arytmetyka konfliktu karabaskiego, „Portal Geopolityka.org”, http://www.geopolityka.org/programy/panstwa-nieuznawane/gorski-karabach/rizwangusejnow-arytmetyka-konfliktu-karabaskiego (13.03.2021)

34. Hypś M., Armenia chce kolejne Su-30SM, „Konflikty.pl”, https://www.konflikty.pl/aktualnosci/wiadomosci/armenia-chce-kolejne-su-30sm/ (14.04.2021)

35. Jafarova E., Russian military shipments to Armenia - a dangerous escalation?, "Euractiv", https://www.euractiv.com/section/azerbaijan/opinion/russian-militaryshipments-to-armenia-a-dangerous-escalation/ (14.04.2021)

36. Jafarova E., Russian military shipments to Armenia - a dangerous escalation?, "Euractiv", https://www.euractiv.com/section/azerbaijan/opinion/russian-militaryshipments-to-armenia-a-dangerous-escalation/ (11.04.2021)

37. Jarosiewicz A., Azerbejdżan - gniew ludu, „Analizy OSW”, https://www.osw.waw.pl/pl/publikacje/analizy/2016-01-20/azerbejdzan-gniew-ludu (13.04.2021)

38. Jarosiewicz A., Azerbejdżan - niskie ceny ropy testem dla stabilności, „Analizy OSW", $\quad$ https://www.osw.waw.pl/pl/publikacje/analizy/2015-02-12/azerbejdzanniskie-ceny-ropy-testem-dla-stabilnosci (13.04.2021)

39. Jarosiewicz A., Falkowski M., Wojna czterodniowa w Górskim Karabachu, „Analizy OSW", $\quad$ https:/www.osw.waw.pl/pl/publikacje/analizy/2016-04-06/wojnaczterodniowa-w-gorskim-karabachu (14.04.2021)

40. Jarosiewicz A., Strachota K., Górski Karabach - rozmrażanie konfliktu, „Komentarze OSW", nr 65/2011.

41. Kolarz S., Status prawny Górskiego Karabachu - porównanie ze statusem prawnym Kosowa, „Folia Iuridica Universitatis Wratislaviensis”, nr 5(1)/2016

42. Kucera J., Aliyev airs grievances to Putin over arms shipments to Armenia, "Eurasianet", https://eurasianet.org/aliyev-airs-grievances-to-putin-over-armsshipments-to-armenia (13.03.2021) 
43. Kuczyński M., Krwawiąca Europa. Konflikty zbrojne i punkty zapalne w latach 19902000. Tło historyczne i stan obecny, Warszawa 2001.

44. Kwiatkiewicz P., Azerbejdżan: ukształtowanie niepodległego państwa, Toruń 2009.

45. Kwiatkiewicz P., Przemiany polityczne w Azerbejdżanie. Od republiki radzieckiej do współczesnego państwa. Toruń 2013.

46. Legieć A., Państwa Kaukazu Południowego wobec COVID-19, „Biuletyn PISM”, nr $92(2024) / 2020$.

47. Maszkiewicz M., Repatriacja czy repatriotyzacja? Wybrane problemy polskich strategii politycznych wobec rodaków za wschodnią granicą (1986-1990), Wojnowice 2017.

48. Materski W., Gruzja, Warszawa 2000.

49. Mehdiyev M., Baku Denies Speculations About Joining Russia-led Military Bloc, "Caspian News", https://caspiannews.com/news-detail/baku-denies-speculationsabout-joining-russia-led-military-bloc-2019-9-20-0/ (14.04.2021)

50. Musajew T., Kosowo a roszczenia Armenii wobec regionu Górskiego Karabachu Azerbejdżanu. Porównawcza analiza prawna, Warszawa 2013.

51. OSCE Minsk Group, https://www.osce.org/mg (13.02.2021)

52. Palowski J., Górski Karabach: Drony uderzeniowe kontra przeciwlotnicze Osy, „Defence24”, https://www.defence24.pl/gorski-karabach-drony-uderzeniowe-kontraprzeciwlotnicze-osy (23.06.2021)

53. Paszynian zwrócił się do Kremla z prośbą o wsparcie, portal Studium Europy Wschodniej Uniwersytetu Warszawskiego, https://studium.uw.edu.pl/paszynianzwrocil-sie-do-kremla-z-prosba-o-wsparcie/ (13.03.2021)

54. Popescu N., How the EU became marginalised in Nagorno-Karabakh, "European Council on Foreign Relations ecfr.eu", https://ecfr.eu/article/commentary_how_europe_became_marginalised_in_nagorno_ka rabakh/ (17.03.2021)

55. Potocki J., Kaukaska kwadratura, Warszawa 2012.

56. Potocki M., Wirusowa wojna zastępcza. Konflikt Armenia - Azerbejdżan odwraca uwagę od skutków pandemii, „Dziennik. Gazeta Prawna”, https://www.gazetaprawna.pl/wiadomosci/artykuly/1486416,konflikt-armeniaazerbejdzan-odwraca-uwage-skutki-pandemii.html (17.03.2021)

57. Resolution 822 (1993) / adopted by the Security Council at its 3205th meeting, on 30 April 1993, United Nations Digital Library, https://digitallibrary.un.org/record/165604 (21.05.2021)

58. Resolution 853 (1993) / adopted by the Security Council at its 3259th meeting, on 29 July 1993, United Nations Digital Library, https://digitallibrary.un.org/record/170257 (21.05.2021)

59. Resolution 874 (1993) / adopted by the Security Council at its 3292nd meeting, on 14 October 1993, United Nations Digital Library, https://digitallibrary.un.org/record/174420 (21.05.2021)

60. Resolution 884 (1993) / adopted by the Security Council at its 3313th meeting, on 12 November 1993, United Nations Digital Library, https://digitallibrary.un.org/record/176731 (21.05.2021) 
61. Rodkiewicz W., Rosyjsko-tureckie napięcia za parawanem normalizacji, „Analizy OSW", https://www.osw.waw.pl/pl/publikacje/analizy/2017-03-15/rosyjsko-tureckienapiecia-za-parawanem-normalizacji (28.04.2021)

62. Rokita Z., Historia konfliktu górskokarabaskiego i jego miejsce w polityce zagranicznej Federacji Rosyjskiej, „Pisma Humanistyczne”, (7)/2010.

63. Rosyjskie „siły pokojowe” w Karabachu, „Warsaw Institute”, https://warsawinstitute.org/pl/rosyjskie-sily-pokojowe-w-karabachu/ (17.04.2021)

64. Russia's Security Guarantees for Armenia Don't Extend to Karabakh, Putin Says, "The Moscow Times", https://www.themoscowtimes.com/2020/10/07/russiassecurity-guarantees-for-armenia-dont-extend-to-karabakh-putin-says-a71687 (22.05.2021)

65. Sabak J., Czego uczy nas „wojna dronów” w Górskim Karabachu?, „Defence24”, https://www.defence24.pl/potrzebna-zmiana-tytulu-na-yt-czego-uczy-nas-wojnadronow-w-gorskim-karabachu-skaner-defence24 (27.05.2021)

66. Sadłowski M., Organizacja Układu o Bezpieczeństwie Zbiorowym. Prawnoinstytucjonalne aspekty funkcjonowania, Toruń 2017.

67. Shiriyev Z., Azerbaijan's Relations with Russia Closer by Default? Research Paper, Russia and Eurasia Programme, (28.05.2021)

68. Solak J., Mołdawia. Republika na trzy pęknięta. Historyczno-społeczny, militarny i geopolityczny wymiar ,zamrożonego konfliktu o Naddniestrze, Toruń 2009.

69. Strachota K., Marszewski M., Rosyjski triumf w Syrii, „Analizy OSW", https://www.osw.waw.pl/pl/publikacje/analizy/2019-10-24/rosyjski-triumf-w-syrii (11.03.2021)

70. Świerczyński M., Właśnie zobaczyliśmy, jak mogą wyglądać następne wojny, „Polityka”, https://www.polityka.pl/tygodnikpolityka/swiat/1981804,1,wlasniezobaczylismy-jak-moga-wygladac-nastepne-wojny.read (27.05.2021)

71. Świętochowski T., Azerbejdżan i Rosja. Kolonializm, islam i narodowość w podzielonym kraju, Warszawa 1998.

72. Świętochowski T., Azerbejdżan, Warszawa 2006.

73. Szefowie MSZ Armenii i Azerbejdżanu spotkają się w Waszyngtonie, portal Studium Europy Wschodniej Uniwersytetu Warszawskiego, https://studium.uw.edu.pl/szefowie-msz-armenii-i-azerbejdzanu-spotkaja-sie-wwaszyngtonie/ (22.03.2021)

74. Szopa M., Su-30SM dla Armenii „Defence24”, https://www.defence24.pl/su-30smdla-armenii (02.03.2021)

75. Tureckie F-16 „wsparciem” dla Azerbejdżanu, „Defense24”, https://www.defence24.pl/tureckie-f-16-wsparciem-dla-azerbejdzanu-wideo (23.04.2021)

76. Verluise P., Armenia in Crisis: The 1988 Earthquake, Detroit 1995.

77. Wagabow F. (red.), Górny Karabach. Wydarzenia, fakty, liczby, Baku-Weten 2005.

78. What Is Russia's Role in the Armenia-Azerbaijan Conflict?, "The Moscow Times", https://www.themoscowtimes.com/2020/09/28/what-is-russias-role-in-the-armeniaazerbaijan-conflict-a71567 (14.03.2021) 
79. Womack H., Refugees and fresh graves confirm massacre by Armenians - Azeris hunted down and shot in the forest, "The Independent", https://justiceforkhojaly.org/content/refugees-and-fresh-graves-confirm-massacrearmenians-\%E2\%80\%93-azeris-hunted-down-and-shot-forest (11.02.2021)

80. Wróbel, Naddniestrze J., [w:] K. Strachota (red.), Konflikty na obszarze postradzieckim. Stan obecny. Perspektywy uregulowania. Konsekwencje, „Prace OSW", nr 9/2003.

81. Żochowski P., Białoruski klincz. Kolejny tydzień protestów, „Analizy OSW”, https://www.osw.waw.pl/pl/publikacje/analizy/2020-09-21/bialoruski-klincz-kolejnytydzien-protestow (17.02.2021)

82. Васадзе Г., Політолог, ведучий програми «Велика гра», Тбілісі, Грузія Війна за Нагірний Карабах. Погляд з Грузії, „«Чорноморська безпека» Аналітичний часопис", No 1(39)2021.

83. Заблоцький В., Визволення Нагірного Карабаху. Військово-технічні та оперативно-тактичні Аспекти, „«Чорноморська безпека» Аналітичний часопис”, No 1(39)2021.

84. Современное состояние ПВО стран - бывших советских союзных республик.

Часть 6-я, „Военное обозрение”, https://topwar.ru/101936-sovremennoe-sostoyaniepvo-stran-byvshih-sovetskih-soyuznyh-respublik-chast-6-ya.html (14.04.2021) 